\title{
Developing photovoltaic cells parameter estimation algorithm based on equilibrium optimization technique
}

\author{
Abdelhady Ramadan*, Salah Kamel*****, Nabil Neggaz** and Ali S. Alghamdi*** \\ * Department of Electrical Engineering, Faculty of Engineering, Aswan University, Aswan, Egypt \\ ** Université des Sciences et de la Technologie d'Oran Mohamed Boudiaf, USTO-MB, BP 1505, EL M'naouer, 31000 Oran, Algeria \\ *** Department of Electrical Engineering, College of Engineering, Majmaah University, Al-Majmaah 11952, Saudi Arabia \\ **** Corresponding Author: skamel@aswu.edu.eg
}

$\begin{array}{ll}\text { Submitted } & : 23 / 08 / 2020 \\ \text { Revised } & : 08 / 04 / 2021 \\ \text { Accepted } & : 27 / 04 / 2021\end{array}$

\begin{abstract}
Nowadays, all the world does its best to develop the power generation systems that depend on nature in order to reduce the dependence on fuel. Photovoltaic (PV) systems are considered one of the most important renewable energy resources. Scientific research has gained a high interest, especially in PV cell modeling and parameter estimation. The estimation of optimum parameters for the PV model has been considered the main target of the paper optimization problem. Equilibrium optimization (EO) algorithm is considered one of optimization algorithms inspired from nature physical phenomena. EO algorithm has been inspired from the nature physical process of controlling mass balance through specific volume until reaching equilibrium state. In this paper, an EO algorithm has been proposed and applied to prepare a mathematical model for photovoltaic solar cell. The challenge in this optimization problem is the nonlinearity in PV solar cell characteristic. The EO algorithm has been evaluated through the following items. EO has been applied to estimate the parameters of different PV models such as single, double, and triple PV models, which have different complexity, applying the previous item for real PV application. The obtained results have been compared though different functions such as root mean square value and absolute mean error. In all cases, EO obtained results have been compared with the more recent optimization algorithms such as particle swarm optimization (PSO), teaching learn based optimization (TLBO), and Harries Hawk optimization (HHO). From the all obtained results, EO algorithm gives more accurate PV models in comparison with other optimization algorithms.
\end{abstract}

Keywords: Equilibrium optimization algorithm; Photo voltaic; Single diode; Double diode; Triple diode PV model.

\section{INTRODUCTION}

Renewable energy gained a great concern from the entire world in recent days. The lack of nature fuel resources and the high cost of fuel production are the main cause of the renewable energy being spreading. One of the important renewable energy resources is the solar energy. Solar energy is converted into electricity through solar cells. Sunlight has a huge number of photons. Each photon has a specific amount of energy. When a solar cell is exposed to the sunlight, the solar cell has absorbed the photons, and the photons' energy is converted into electrical current through 
the cell. The current produced by the cell can be measured through different ways (open-circuit current and shortcircuit current). These types of currents determine the cell efficiency [1,2]. The electrical energy produced from the cells is directly used or stored in batteries for night use [3]. The amount of electricity produced from cells depends on different environmental and manufactural factors such as the sunlight, ambient temperature, cell position to sunlight, and cell efficiency. So, it became extremely important to develop a simulation model for the PV system specially for systems installed in variable climate. Developing an accurate model for the PV system is extremely important to discuss the characteristic and behavior for each PV system in case of variant environmental conditions. The challenge in the model development is the nonlinear characteristics for the solar cell [4-6].

The recent models in literature are the models depending on electrical diodes because they have electrical characteristics similar to those of the solar cells.

Single diode model (SDM), double diode model (DDM), and triple diode model (TDM) are different models depending on the number of diodes in each model. SDM is considered the simplest one because it has one diode as a main component and two resistances (series and shunt resistance). The total number of estimated parameters in SDM is five parameters, which considered a simple number for estimation [7-9]. The DDM has two diodes as main components and two resistances (series and shunt resistance). The total number of estimated parameters in DDM is seven parameters. DDM is more accurate than SD [10-13]. The TDM has three diodes as main components and two resistances (series and shunt resistance). The total number of estimated parameters in TDM is nine parameters. TDM is more accurate than SD and DDM, despite of its complexity due to large number of estimated parameters [14-18].

There are a lot of optimization algorithms in the literature, but the most popular techniques are deterministic and stochastic techniques. Deterministic techniques are more suitable for linear than nonlinear optimization problems [19]. Stochastic techniques have more advantages than deterministic techniques because they generate and use random variables and then search the domain in global manner to find the best solution.

Metaheuristic algorithms are considered the most popular stochastic techniques [20]. Metaheuristic algorithms are inspired from different nature resources such as human behavior (TLBO) [21-23], human body (genetic algorithm (GA) ) [24], animals, birds, and other insects hunting behavior and food way demand (Grey Wolf Optimization (GWO)) [25 and 26], Harries Hawk optimization (HHO) [27], PSO [28 - 30], and chaotic whale optimization [31 and 32]. A physical theory example is equilibrium optimization. Metaheuristic algorithms are more distinct than others in simplicity and general applicability.

Equilibrium optimization algorithm is considered one of metaheuristic algorithms inspired from natural physical theory. EO is inspired from controlling mass balance through specific volume until reaching equilibrium state [33]. In this paper, three PV models (SD, DD, and TD) are discussed, and the EO algorithm is also presented. The EO algorithm is applied to estimate the parameter of PV systems for different PV model. The behavior of EO in parameter estimation is tested by applying it to different real system.

The main contribution of this paper can be summarized as follows:

- $\quad$ EO is presented to be applied for PV model parameter estimation.

- $\quad \mathrm{SD}, \mathrm{DD}$, and TD models are presented as an example for PV models, and their parameter estimation is considered as the optimization problem.

- The performance of EO is tested through different applications:

- Application one: EO has been used to estimate the parameters of SD and DD models considering the real data measured from $57 \mathrm{~mm}$ diameter commercial silicon R.T.C France solar cell (under $1000 \mathrm{~W}=\mathrm{m} 2$ at $\left.33^{\circ} \mathrm{C}\right)$. 
- The applicability of EO with complex model has been tested by estimating TD model parameters through real PV panel application.

- $\quad$ The real data of polycrystalline PV panel STM6-120/36 have been considered for the real PV panel application.

- -By comparing the obtained results, the EO results are more accurate than those of other recent optimization algorithms.

The rest of this paper is arranged as follows:

Section 2 presents the PV model and the optimization problem. Section 3 describes the EO algorithm. The results and application are discussed in section 4. Section 5 presents the conclusion.

\section{MATHEMATICAL PV MODELS AND THE OPTIMIZATION PROBLEM}

The solar cell electrical characteristics are similar to P-N junction (diode) electrical characteristics as shown in Figs. 1 and 2. Therefore, the main element in the equivalent circuit of each model is the diode. Every model is distinct than others by the number of diodes in the model equivalent circuit. In this section, a brief discretion about the most popular PV model has been presented, as well as the optimization problem for each model. In each model, the advantages and drawbacks have been discussed [34]. These models are arranged from simple to complex as SD, DD, and TD.

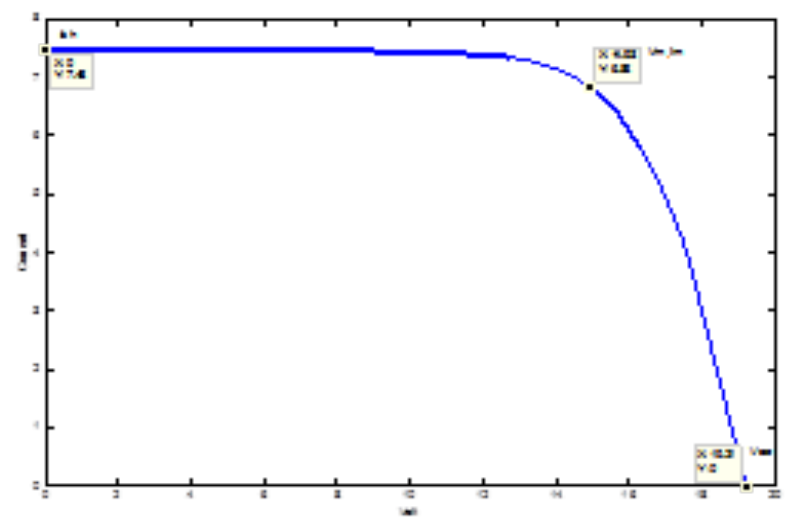

Figure 1. Current Vs voltage characteristics for polycrystalline PV panel.

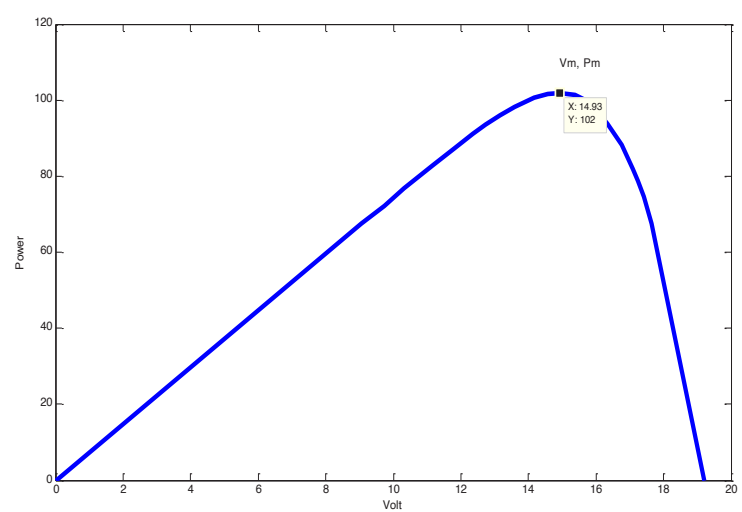

Figure 2. Power Vs voltage characteristics for polycrystalline PV panel. 


\section{A. SD model}

The SD model is considered the simplest model as shown in the model equivalent circuit of this model in Fig. 3. The model has five parameters listed as follows:

- Solar cell photo generation current $\left(\mathrm{I}_{\mathrm{ph}}\right)$ represents one current source.

- Diode current $\left(\mathrm{I}_{\mathrm{sd}}\right)$ represents the P-N junction characteristics.

- Equivalent series resistance is represented by $\mathrm{R}_{\mathrm{s}}$.

- Equivalent shunt resistance is represented by $\mathrm{R}_{\text {sh. }}$.

- Diode ideality factor (n).

The output current (It) is calculated through the following equations:

$$
I_{t}=I_{p h}-I_{s d}-I_{s h}
$$

$$
I_{t}=I_{p h}-I_{s d}\left[\exp \left(\frac{q\left(V_{t}+R_{s} * I_{t}\right)}{\eta * K * T}\right)-1\right]-\frac{\left(V_{t}+R_{s} * I_{t}\right)}{R_{s h}}
$$

The SD model estimated parameters are $\left[\mathrm{R}_{\mathrm{s}}, \mathrm{R}_{\mathrm{sh}}, \mathrm{I}_{\mathrm{ph}}, \mathrm{I}_{\mathrm{sd}}, \mathrm{\eta}\right]$. The five parameters can be represented in one vector $\mathrm{x}=\left[\mathrm{x}_{1}, \mathrm{x}_{2}, \mathrm{x}_{3}, \mathrm{x}_{4}, \mathrm{x}_{5}\right]$; hence, the optimization problem is described by the following equation:

$$
f_{S D}\left(V_{t}, I_{t}, X\right)=I_{t}-X_{3}+X_{4}\left[\exp \left(\frac{q\left(V_{t}+R_{s} * I_{t}\right)}{X_{5} * K * T}\right)-1\right]+\frac{\left(V_{t}+X_{1} * I_{t}\right)}{X_{2}}
$$

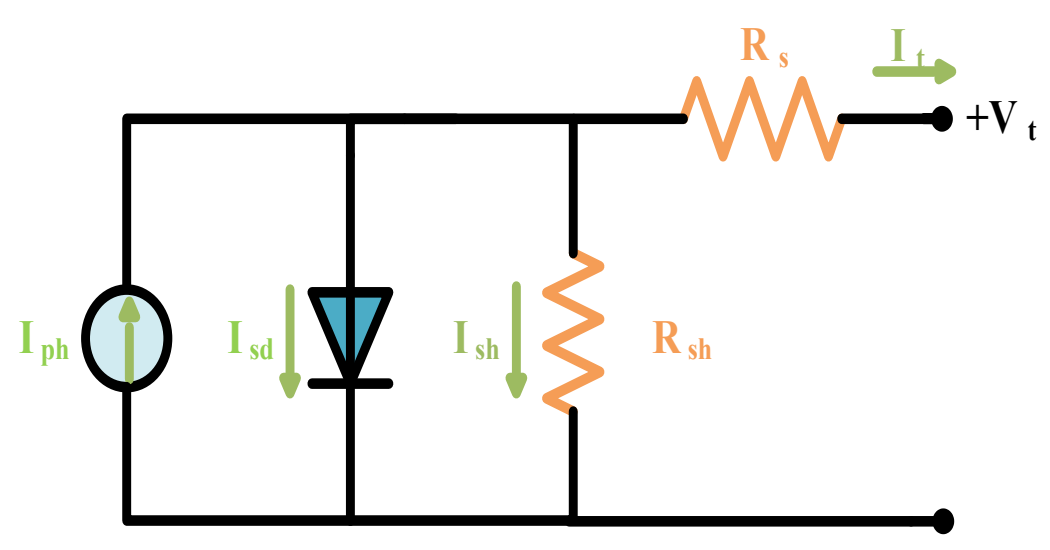

Figure 3. SD model.

\section{B. DD model}

The DD model is differentiated from SD model by 2 diodes as shown in Fig. 4. This model is represented by (4) and (5). 


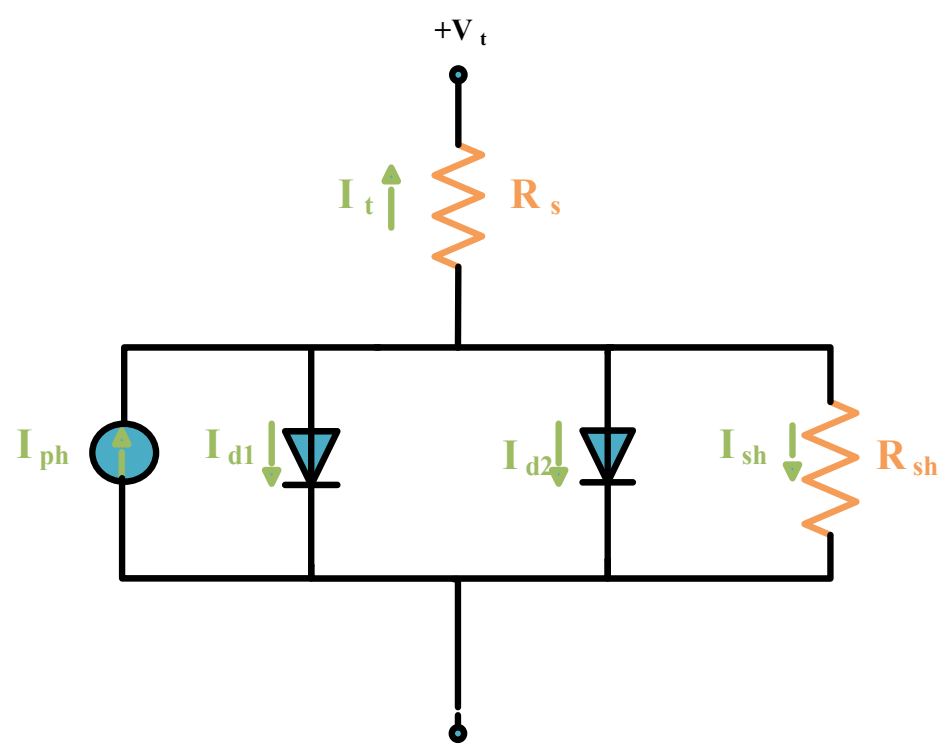

Figure 2. DD model.

$$
\begin{aligned}
& I_{t}=I_{p h}-I_{d 1}-I_{d 2}-I_{s h} \\
& I_{t}=I_{p h}-I_{d 1}\left[\exp \left(\frac{q\left(V_{t}+R_{s} * I_{t}\right)}{\eta_{1} * K * T}\right)-1\right] \\
& -I_{d 2}\left[\exp \left(\frac{q\left(V_{t}+R_{s} * I_{t}\right)}{\eta_{2} * K * T}\right)-1\right]-\frac{\left(V_{t}+R_{s} * I_{t}\right)}{R_{s h}}
\end{aligned}
$$

In the DD model, seven estimated parameters are considered $\left[R_{s}, R_{s h}, I_{p h}, I_{d 1}, I_{d 2}, \eta_{1}, \eta_{2}\right]$, and they can be represented in one vector $\mathrm{x}=\left[\mathrm{x}_{1}, \mathrm{x}_{2}, \mathrm{x}_{3}, \mathrm{x}_{4}, \mathrm{x}_{5}, \mathrm{x}_{6}, \mathrm{x}_{7}\right]$; hence, the optimization problem is described by the following equation:

$$
\begin{aligned}
& f_{D D}\left(V_{t}, I_{t}, X\right)=I_{t}-X_{3}+X_{4}\left[\exp \left(\frac{q\left(V_{t}+R_{s} * I_{t}\right)}{X_{6} * K * T}\right)-1\right] \\
& +X_{5}\left[\exp \left(\frac{q\left(V_{t}+R_{s} * I_{t}\right)}{X_{7} * K * T}\right)-1\right]+\frac{\left(V_{t}+X_{1} * I_{t}\right)}{X_{2}}
\end{aligned}
$$

\section{TD model}

The TD equivalent circuit is the same as DD, taking into consideration the leakage current, which is represented by a third diode as shown in Fig. 5 . 


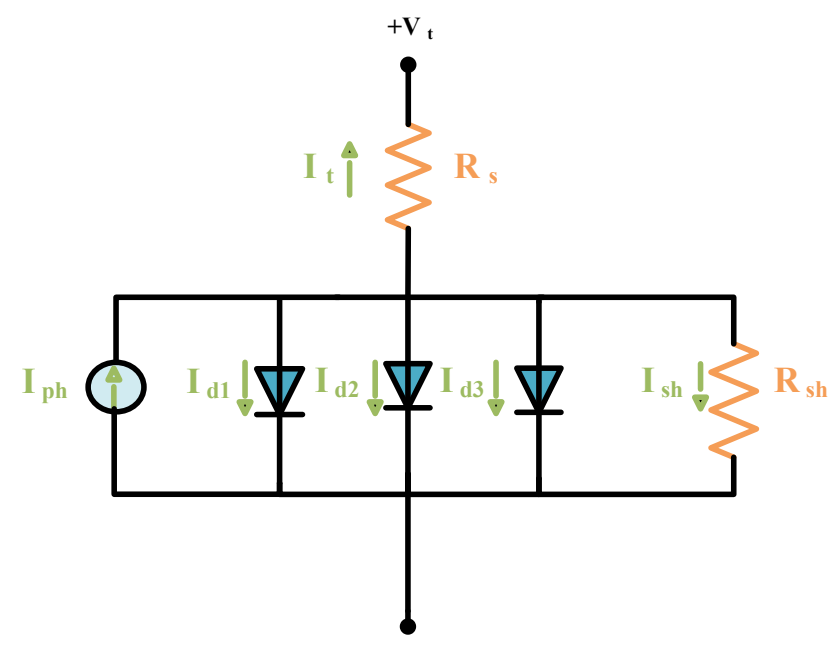

FIGURE 5. TD model mathematical model.

Equations (7) and (8) describe the mathematical model of TD model:

$I_{t}=I_{p h}-I_{d 1}-I_{d 2}-I_{d 3}-I_{s h}$

$$
\begin{aligned}
& I_{t}=I_{p h}-I_{d 1}\left[\exp \left(\frac{q\left(V_{t}+R_{s} * I_{t}\right)}{\eta_{1} * K * T}\right)-1\right] \\
& -I_{d 2}\left[\exp \left(\frac{q\left(V_{t}+R_{s} * I_{t}\right)}{\eta_{2} * K * T}\right)-1\right] \\
& -I_{d 3}\left[\exp \left(\frac{q\left(V_{t}+R_{s} * I_{t}\right)}{\eta_{3} * K * T}\right)-1\right]-\frac{\left(V_{t}+R_{s} * I_{t}\right)}{R_{s h}}
\end{aligned}
$$

In the TD model, nine estimated parameters are considered [ $\left.\mathrm{R}_{\mathrm{s}}, \mathrm{R}_{\mathrm{sh}}, \mathrm{I}_{\mathrm{ph}}, \mathrm{I}_{\mathrm{d} 1}, \mathrm{I}_{\mathrm{d} 2}, \mathrm{I}_{\mathrm{d} 3}, \eta_{1}, \eta_{2}, \eta_{3}\right]$, and they can be represented in one vector $\mathrm{x}=\left[\mathrm{x}_{1}, \mathrm{x}_{2}, \mathrm{x}_{3}, \mathrm{x}_{4}, \mathrm{x}_{5}, \mathrm{x}_{6}, \mathrm{x}_{7}, \mathrm{x}_{8}, \mathrm{x}_{9}\right]$; hence, the optimization problem is described by the following equation:

$$
\begin{aligned}
& f_{T D}\left(V_{t}, I_{t}, X\right)=I_{t}-X_{3}+X_{4}\left[\exp \left(\frac{q\left(V_{t}+R_{s} * I_{t}\right)}{X_{7} * K * T}\right)-1\right] \\
& +X_{5}\left[\exp \left(\frac{q\left(V_{t}+R_{s} * I_{t}\right)}{X_{8} * K * T}\right)-1\right]+X_{6}\left[\exp \left(\frac{q\left(V_{t}+R_{s} * I_{t}\right)}{X_{9} * K * T}\right)-1\right] \\
& +\frac{\left(V_{t}+X_{1} * I_{t}\right)}{X_{2}}
\end{aligned}
$$




\section{EO ALGORITHM}

A new metaheuristic algorithm based on physics laws is proposed in [24], namely, equilibrium optimizer (EO). Firstly, the purpose of EO is to solve optimization problems. Secondly, other applications are realized as thresholding image segmentation [25]. The mathematical formulation of the EO algorithm is given as follows:

\section{Step 1: Initialization}

In this step, EO uses a group of search agents representing the concentration vectors that are candidate solutions. These initial concentration vectors are randomly generated as

$$
\vec{v}_{i}=L b_{i}+\operatorname{rand}^{*}\left(U b_{i}-L b_{i}\right) ; i=1,2, \ldots, N
$$

where denotes the concentration vector of the ith solution, the upper and lower bounds for the problem domain, respectively, rand the random number generator in the range of $[0 ; 1]$, and $\mathrm{N}$ the number of search agents.

\section{Step 2: Equilibrium pool and candidates}

$$
\vec{C}_{\text {eq.pool }}
$$

In an optimization algorithm, there are the objective function and best solution. For instance, EO, as we call it, searches for the equilibrium state of the system. When reaching the equilibrium state, EO reaches the near-optimal solution. In the optimization process, EO is unaware of the level of concentrations to achieve the equilibrium state. Hence, it allocates the best four solutions found so far, as well as one more solution containing the average of the best four solutions. These five candidate solutions help EO in the process of exploration and exploitation. Here, the first four candidate solutions assist EO to have diversification, and the average solution works for exploitation. These five candidate solutions are stored in an equilibrium pool:

$$
\vec{C}_{\text {eq.pool }}=\left[\vec{C}_{\text {eq.(1) }} ; \vec{C}_{\text {eq.(2) }} ; \vec{C}_{\text {eq.(3) }} ; \vec{C}_{\text {eq.(4) }} ; \vec{C}_{\text {eq.(avg) }}\right]_{(10)}
$$

\section{Step 3: updating the concentration}

To balance between exploration and exploitation, EO uses the following term. Because the turnover rate varies over time, is a random vector between 0 and 1 .

$$
\vec{F}=e^{-\vec{\lambda}\left(t-t_{0}\right)}
$$

where $t$ decreases with the iteration (it) increment as

$$
t=\left(1-\frac{i t}{t_{\max }}\right)^{\left(a_{2} * \frac{i t}{t_{\max }}\right)}
$$


where it and tmax are the present and the maximum number of iterations, respectively. a2 is a constant used to control the exploitation. a1 is supposed to enhance the exploitation as follows:

$$
\overrightarrow{t_{0}}=\frac{1}{\vec{\lambda}} \ln \left(-a_{1} \operatorname{sign}(\vec{r}-0.5)\left(1-e^{-\vec{\lambda} t}\right)\right)+t
$$

where a1 is a constant used to manage the exploration when it is higher, the exploration is better, and the exploitation is lower. Opposite to a1, a2 is a constant used to control the exploitation. When a2 is higher, the exploitation is enhanced, and the exploration is lowered. The generation rate $(\mathrm{R})$ is another term used to improve the intensification operator and is formulated as follows:

$$
\vec{R}=\vec{R}_{0} * e^{-\vec{\lambda}\left(t-t_{0}\right)}
$$

where is a random generator $[0,1]$ and is the initial value:

$$
\begin{gathered}
\vec{R}_{0}=\overrightarrow{R C P} *\left(\overrightarrow{c_{e q}}-\vec{\lambda} * \vec{C}\right) \\
\overrightarrow{R C P}=\left\{\begin{array}{cc}
0.5 r_{1} & r_{2} \succ 0.5 \\
0 & \text { else }
\end{array}\right.
\end{gathered}
$$

where $\mathrm{r} 1$ and $\mathrm{r} 2$ are the random generators $[0,1]$. Here, represents the generation rate control parameter that decides the generation rate to be applied to the updating process based on a probability RP. The updating equation of EO is as follows:

$$
\vec{C}=\overrightarrow{c_{e q}}+\left(\vec{C}-\overrightarrow{c_{e q}}\right) * \vec{F}+\frac{\vec{R}}{\vec{\lambda} * V} *(1-\vec{F})
$$

where $\mathrm{V}$ is equal to 1 . The main steps of $\mathrm{EO}$ are explained by the framework depicted in Fig. 6. 


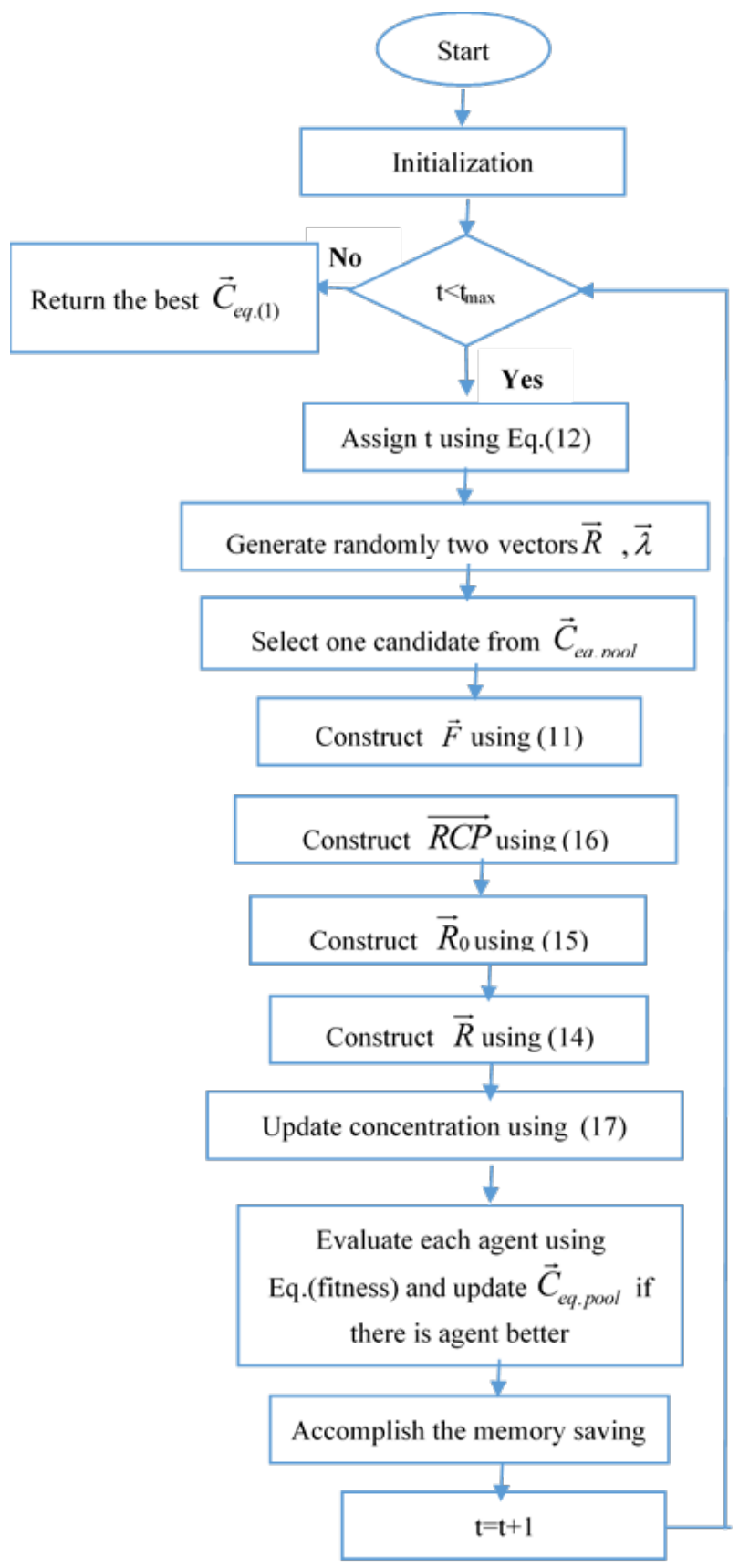

Figure 6. EO flowchart.

\section{SIMULATION RESULTS}

The simulation results are presented through two applications. To evaluate the performance of the EO algorithm, it has been used to estimate the parameters of PV model through different real applications. The results of EO have been compared with other algorithms. 


\section{A. Application 1}

In this application, the EO is applied for estimating the parameters of SD and DD PV models. The real data considered in this application is the measured data from $57 \mathrm{~mm}$ diameter commercial silicon R.T.C France solar cell (under $1000 \mathrm{~W}=\mathrm{m} 2$ at $33^{\circ} \mathrm{C}$ ) Table 2 [34]. A comparison between EO and seven algorithms (TLBO, HHO, PSO, PO, MRFO, and JAYA) is implemented for SD and DD models. The parameters of each algorithm have been presented in Table 1.

Table 1. Parameter setting for each compared algorithm.

\begin{tabular}{|c|c|c|c|l|}
\hline Algorithm & \multicolumn{4}{|c|}{ Parameter setting } \\
\hline EO & $\mathrm{V}=1$ & $\mathrm{a}_{1}=2$ & $\mathrm{a}_{2}=1$ & $\mathrm{GP}=0.5$ \\
\hline $\mathrm{TLBO}$ & $\mathrm{NP}=1000$ & $\mathrm{TF}=$ randi $([12]$ & & \\
\hline $\mathrm{HHO}$ & $\mathrm{NP}=1000$ & beta $=1.5$ & & \\
\hline PSO & $\mathrm{NP}=1000$ & wdamp $=0.99$ & $\mathrm{c} 1=1.5$ & $\mathrm{c}_{2}=2.0$ \\
\hline PO & \multicolumn{2}{|c|}{ lambda $=1.0$} & & \\
\hline MRFO & $\mathrm{NP}=1000$ & $\mathrm{~S}=2$ & & \\
\hline JAYA & gen $=1$ & & & \\
\hline
\end{tabular}

\section{SD Results}

Based on the optimization problem of SD model equation 3, EO has been applied to estimate five parameters. Table 2 presents the SD model estimated five parameters for EO and others compared algorithms. The Root Mean Square Error (RMSE)value (Equation 18) for each algorithm has been presented also in Table 1. Table 3 presents the real measurements for voltage and output current, as well as the calculated output currents from the estimated parameters by each algorithm. Fig. 7 presents the absolute error between real output current and the output current calculated from the parameter estimated from each algorithm (Equation 19). In Fig. 7, the values presented by EO algorithm are closer to zero. Fig. 8 presents the convergence curves for EO and other algorithms. Table 4 represents the minimum, average, maximum, and standard deviation (STD) values for 30-run statistical results. The RMSE values calculated in each run are figured in boxplot for each algorithm as shown in fig. 9. (+) represents the outliers. In figs. 7, 8, and 9, EO algorithm results are more accurate than those of others. For more comparison, current Vs volt and power Vs volt characteristics curves for real system, EO, and other algorithms have been discussed in figs. 10 and 11, respectively. The accuracy of the SD model by developed by EO algorithm is tested through the current Vs volt and power Vs volt characteristics curves at different temperatures as shown in figs. 12 and 13, respectively.

$$
R M S E=\sqrt{\frac{1}{N} \sum_{K=1}^{N} f^{2}\left(V_{t m}, I_{t m}, X\right)}
$$


Absolute_error $=\left|I_{\text {real }}-I_{\text {Calculated }}\right|$

Table 2. ESTIMATED parameter in case of SD obtained by different optimization algorithms.

\begin{tabular}{|c|c|c|c|c|c|c|c|}
\hline & 임 & $\begin{array}{l}\text { O } \\
\stackrel{0}{1}\end{array}$ & $\stackrel{\mathfrak{g}}{\mathrm{E}}$ & $\begin{array}{l}\text { On } \\
\mathscr{O}\end{array}$ & @ & 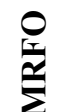 & $\overleftrightarrow{3}$ \\
\hline $\begin{array}{l}\widehat{c} \\
\approx \\
\approx\end{array}$ & $\begin{array}{l}\hat{0} \\
\tilde{\delta} \\
0 \\
0\end{array}$ & $\begin{array}{l}\text { to } \\
\stackrel{0}{0} \\
0\end{array}$ & $\begin{array}{l}\text { to } \\
\text { Oִ } \\
0\end{array}$ & $\begin{array}{l}\text { ț } \\
\stackrel{0}{0} \\
\stackrel{0}{\circ}\end{array}$ & 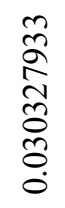 & 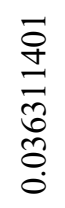 & 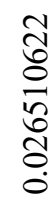 \\
\hline 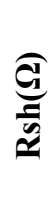 & $\begin{array}{l}\vec{a} \\
\vec{n} \\
\stackrel{n}{n}\end{array}$ & $\underset{i}{\vec{n}}$ & $\begin{array}{l}8 \\
\text { ¿ } \\
\text { i } \\
\text { ñ }\end{array}$ & 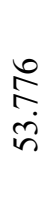 & 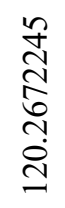 & 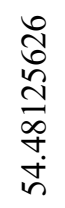 & \&্ণ \\
\hline 氖 & $\begin{array}{l}\infty \\
0 \\
0 \\
0\end{array}$ & $\begin{array}{l}\infty \\
\stackrel{0}{0} \\
\stackrel{0}{0}\end{array}$ & $\begin{array}{l}\overline{\widehat{0}} \\
\stackrel{0}{0}\end{array}$ & 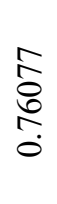 & $\begin{array}{l}0 \\
n \\
\infty \\
\infty \\
\delta \\
0 \\
0 \\
0\end{array}$ & $\begin{array}{l}\infty \\
\stackrel{0}{0} \\
0 \\
0\end{array}$ & 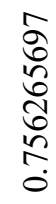 \\
\hline 岕 & $\begin{array}{l}\hat{o} \\
1 \\
\\
\\
\end{array}$ & 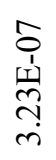 & $\begin{array}{l}\hat{o} \\
\hat{1} \\
\stackrel{1}{+} \\
\hat{i}\end{array}$ & \begin{tabular}{l} 
ô \\
j \\
\multirow{j}{j}{} \\
in
\end{tabular} & $\begin{array}{l}8 \\
\stackrel{1}{1} \\
\text { 1. } \\
= \\
=\end{array}$ & 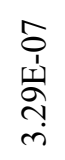 & 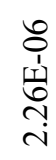 \\
\hline$=$ & $\begin{array}{l}\text { oे } \\
\text { f }\end{array}$ & $\begin{array}{l}\text { oे } \\
\text { f. }\end{array}$ & \begin{tabular}{l}
0 \\
0 \\
\multirow{0}{*}{}
\end{tabular} & 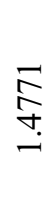 & 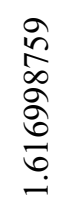 & $\begin{array}{l}\stackrel{0}{\infty} \\
\stackrel{\infty}{f}\end{array}$ & $\begin{array}{l}\hat{\infty} \\
\stackrel{0}{0} \\
o \\
\stackrel{0}{0} \\
\stackrel{2}{n}\end{array}$ \\
\hline$\sum_{\Omega}^{\infty}$ & $\begin{array}{l}\text { ¿े } \\
0 \\
\circ \\
\circ \\
0 \\
0 \\
0\end{array}$ & 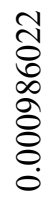 & 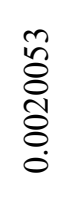 & $\begin{array}{l}\text { ôे } \\
\infty \\
0 \\
0 \\
0 \\
0\end{array}$ & $\begin{array}{l}\infty \\
i \\
0 \\
\infty \\
\hat{0} \\
\delta \\
0 \\
0\end{array}$ & $\begin{array}{l}\hat{0} \\
\infty \\
0 \\
8 \\
0 \\
0\end{array}$ & $\begin{array}{l}n \\
\frac{n}{n} \\
\vdots \\
0\end{array}$ \\
\hline
\end{tabular}


Table 3. The real and output current for each algorithm.

\begin{tabular}{|c|c|c|c|c|c|c|c|c|}
\hline$V$ real & I real & EO & TLBO & HНO & PSO & PO & MRFO & JAYA \\
\hline-0.2057 & 0.764 & 0.7641 & 0.7641 & 0.7687 & 0.7641 & 0.7619 & 0.7641 & 0.7564 \\
\hline-0.1291 & 0.762 & 0.7627 & 0.7627 & 0.7663 & 0.7627 & 0.7613 & 0.7627 & 0.7563 \\
\hline-0.0588 & 0.7605 & 0.7614 & 0.7614 & 0.7641 & 0.7613 & 0.7607 & 0.7614 & 0.7563 \\
\hline 0.0057 & 0.7605 & 0.7602 & 0.7602 & 0.7621 & 0.7601 & 0.7602 & 0.7602 & 0.7563 \\
\hline 0.0646 & 0.76 & 0.7591 & 0.7591 & 0.7602 & 0.7591 & 0.7597 & 0.7591 & 0.7562 \\
\hline 0.1185 & 0.759 & 0.7580 & 0.7580 & 0.7585 & 0.7580 & 0.7592 & 0.7581 & 0.7561 \\
\hline 0.1678 & 0.757 & 0.7571 & 0.7571 & 0.7570 & 0.7571 & 0.7587 & 0.7572 & 0.7560 \\
\hline 0.2132 & 0.757 & 0.7561 & 0.7561 & 0.7554 & 0.7562 & 0.7582 & 0.7562 & 0.7558 \\
\hline 0.2545 & 0.7555 & 0.7551 & 0.7551 & 0.7539 & 0.7552 & 0.7574 & 0.7552 & 0.7551 \\
\hline 0.2924 & 0.754 & 0.7537 & 0.7537 & 0.7520 & 0.7541 & 0.7560 & 0.7538 & 0.7538 \\
\hline 0.3269 & 0.7505 & 0.7514 & 0.7514 & 0.7494 & 0.7524 & 0.7534 & 0.7515 & 0.7511 \\
\hline 0.3585 & 0.7465 & 0.7474 & 0.7474 & 0.7452 & 0.7499 & 0.7487 & 0.7474 & 0.7461 \\
\hline 0.3873 & 0.7385 & 0.7401 & 0.7401 & 0.7378 & 0.7456 & 0.7404 & 0.7402 & 0.7372 \\
\hline 0.4137 & 0.728 & 0.7274 & 0.7274 & 0.7252 & 0.7386 & 0.7263 & 0.7274 & 0.7224 \\
\hline 0.4373 & 0.7065 & 0.7070 & 0.7070 & 0.7050 & 0.7278 & 0.7045 & 0.7070 & 0.6999 \\
\hline 0.4590 & 0.6755 & 0.6753 & 0.6753 & 0.6737 & 0.7117 & 0.6717 & 0.6752 & 0.6668 \\
\hline 0.4784 & 0.632 & 0.6308 & 0.6308 & 0.6297 & 0.6898 & 0.6270 & 0.6306 & 0.6222 \\
\hline 0.4960 & 0.573 & 0.5719 & 0.5719 & 0.5713 & 0.6614 & 0.5691 & 0.5717 & 0.5650 \\
\hline 0.5119 & 0.499 & 0.4996 & 0.4996 & 0.4994 & 0.6273 & 0.4986 & 0.4993 & 0.4958 \\
\hline 0.5265 & 0.413 & 0.4136 & 0.4136 & 0.4137 & 0.5875 & 0.4153 & 0.4133 & 0.4140 \\
\hline 0.5398 & 0.3165 & 0.3175 & 0.3175 & 0.3176 & 0.5436 & 0.3217 & 0.3170 & 0.3219 \\
\hline 0.5521 & 0.212 & 0.2122 & 0.2122 & 0.2120 & 0.4962 & 0.2184 & 0.2115 & 0.2197 \\
\hline 0.5633 & 0.1035 & 0.1023 & 0.1023 & 0.1017 & 0.4472 & 0.1092 & 0.1015 & 0.1108 \\
\hline 0.5736 & -0.01 & -0.0087 & -0.0087 & -0.0098 & 0.3982 & -0.0033 & -0.0096 & -0.0025 \\
\hline 0.5833 & -0.123 & -0.1255 & -0.1255 & -0.1274 & 0.3470 & -0.1232 & -0.1266 & -0.1241 \\
\hline 0.5900 & -0.21 & -0.2085 & -0.2085 & -0.2110 & 0.3109 & -0.2108 & -0.2097 & -0.2143 \\
\hline
\end{tabular}




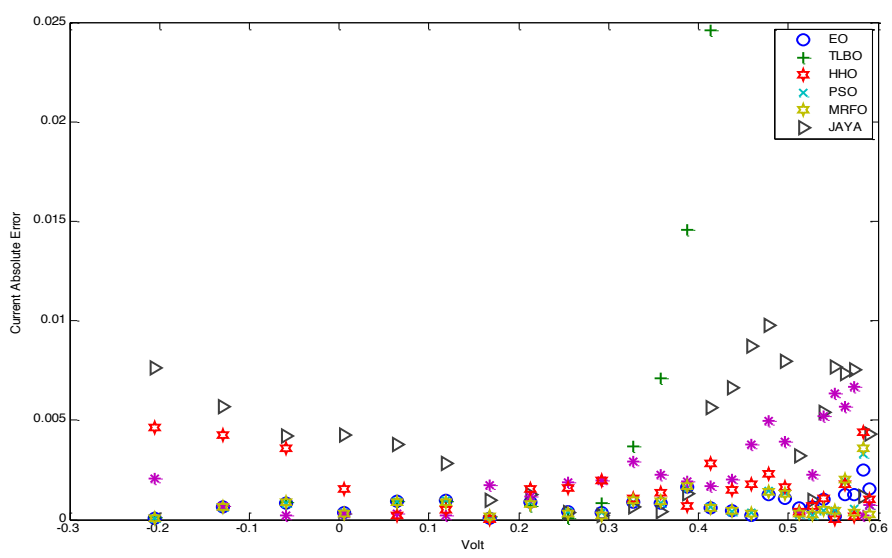

Figure 7. PV output current absolute error for EO and other algorithms.

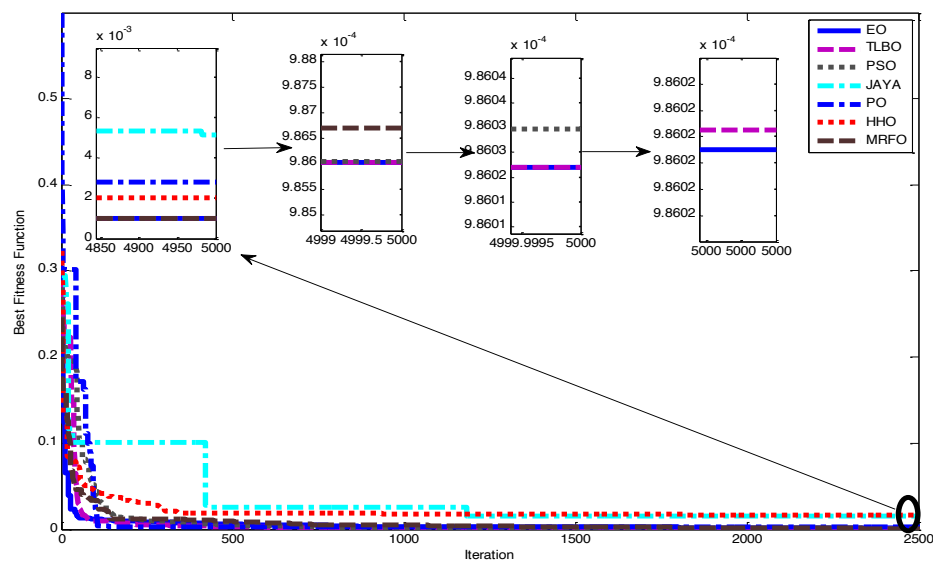

Figure 8. Fitness function for SD model.

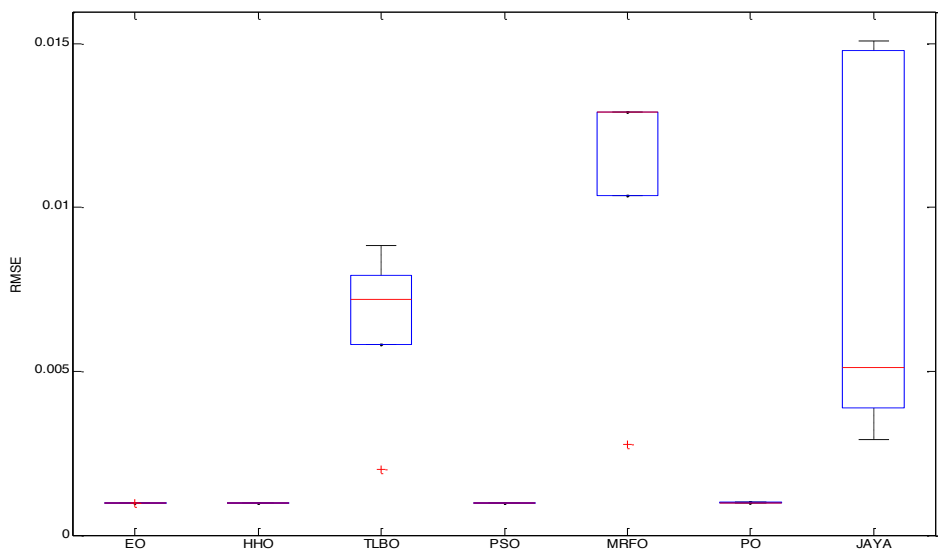

Figure 9. Boxplot for RMSE values of different algorithms for SD model. 
Table 4. The statistical results of all algorithms.

\begin{tabular}{|c|c|c|c|c|}
\hline & Minimum & Average & Maximum & STD \\
\hline EO & 0.000986022 & 0.000986141 & 0.000986546 & $2.27567 \mathrm{E}-07$ \\
\hline TLBO & 0.00098602 & 0.00098602 & 0.00098602 & $3.89754 \mathrm{E}-12$ \\
\hline HHO & 0.0020053 & 0.006543327 & 0.0088269 & 0.002629385 \\
\hline PSO & 0.00098602 & 0.00098603 & 0.00098604 & $5.99571 \mathrm{E}-09$ \\
\hline MRF & 0.002780458 & 0.010876092 & 0.0129 & 0.004525597 \\
\hline JAYA & 0.0009867 & 0.000996299 & 0.0010199 & $1.35517 \mathrm{E}-05$ \\
\hline
\end{tabular}

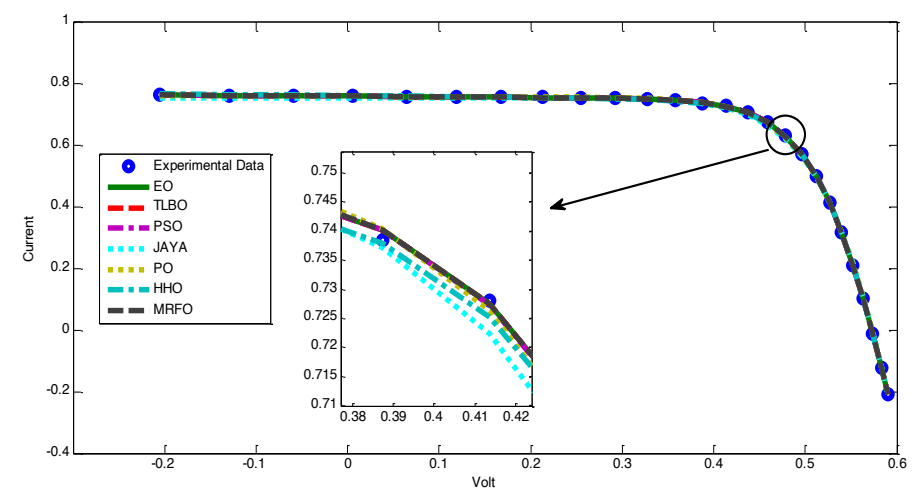

Figure 10. Current Vs volt characteristics for real system, EO, and other algorithms.

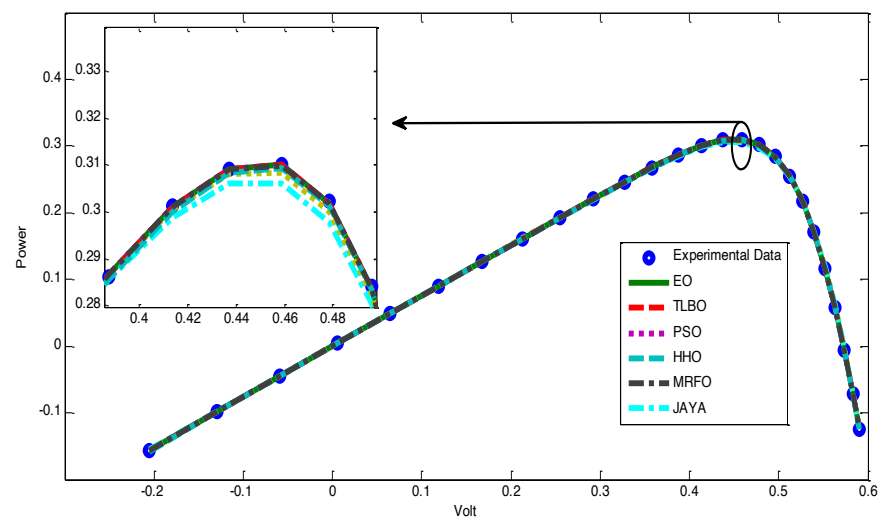

Figure 11. Power Vs volt characteristics for real system, EO, and other algorithms. 


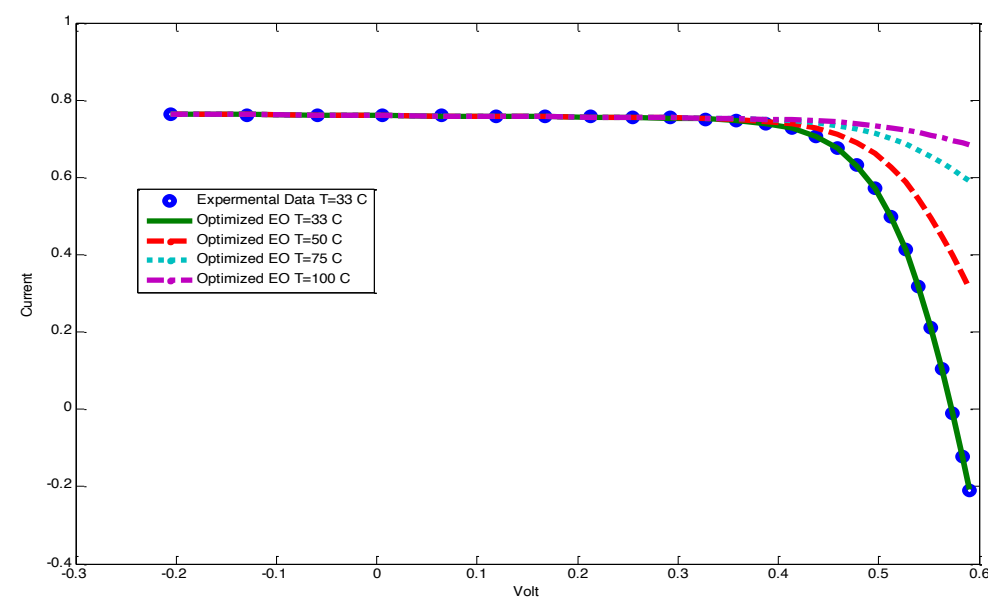

Figure 12. Current Vs volt characteristics for real system and EO algorithm at different temperatures.

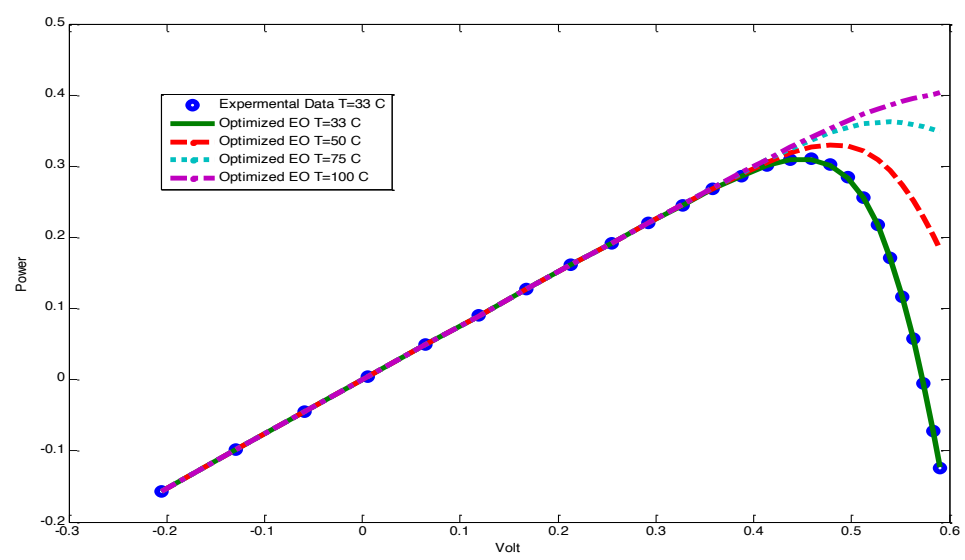

Figure 13. Power Vs volt characteristics for real system and EO algorithm at different temperatures.

\section{DD RESULTS}

Based on the optimization problem of DD model equation 6, EO has been applied to estimate seven parameters of DD model. Table 5 presents the DD model estimated seven parameters for all compared algorithms. RMSE for each algorithm has been presented also in Table 5. Table 6 presents the real measurements for voltage and output current and the calculated output currents from the estimated parameters by each algorithm. Fig. 14 presents the convergence curves for EO and other algorithms. Table 7 represents the minimum, average, maximum, and standard deviation (STD) values for 30-run statistical results. The RMSE values calculated in each run are figured in boxplot for each algorithm as shown in Fig. 15. (+) represents the outliers. Fig. 16 presents the absolute error between real output current and the output current calculated from the parameter estimated from each algorithm. In figs. 14, 15, and 16, EO algorithm results are more accurate than those of others. For more comparison, current Vs volt and power Vs volt characteristics curves for real system for EO and other algorithms have been discussed in figs. 17 and 18, respectively. The accuracy of the SD model developed by EO algorithm has been tested through the current Vs volt and power Vs volt characteristics curves at different temperatures as shown in figs. 19 and 20, respectively. 
Table 5. Estimated parameter in case of DD obtained by different optimization algorithms.

\begin{tabular}{|c|c|c|c|c|c|c|c|}
\hline & $\underset{\text { 외 }}{0}$ & 足 & $\stackrel{0}{\underline{\theta}}$ & $\underset{\mathscr{Q}}{0}$ & $?$ & $\begin{array}{l}0 \\
\sum \\
\Sigma \\
z\end{array}$ & $\underset{\Xi}{\longleftarrow}$ \\
\hline 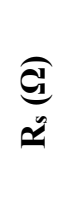 & 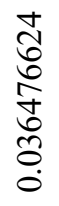 & 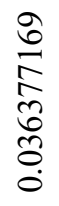 & $\begin{array}{l}n \\
\text { ñ } \\
\hat{\sigma} \\
0 \\
0\end{array}$ & 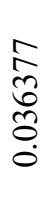 & 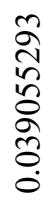 & $\begin{array}{l}\text { a } \\
\bar{N} \\
\hat{\sigma} \\
0 \\
0 \\
0\end{array}$ & 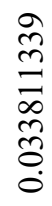 \\
\hline 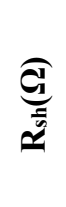 & 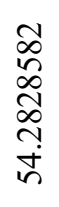 & $\begin{array}{l}\stackrel{N}{\pi} \\
\stackrel{n}{n} \\
\stackrel{n}{n} \\
\stackrel{n}{n}\end{array}$ & 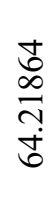 & 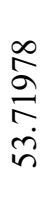 & 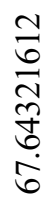 & 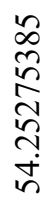 & $\begin{array}{l}8 \\
8 \\
8 \\
\stackrel{2}{2}\end{array}$ \\
\hline$\underset{\Xi}{ٍ}$ & 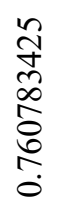 & $\begin{array}{l}\frac{J}{2} \\
\hat{n} \\
\hat{2} \\
0 \\
8 \\
0 \\
0\end{array}$ & $\begin{array}{l}\text { N } \\
\infty \\
0 \\
0 \\
0 \\
0\end{array}$ & 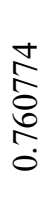 & $\begin{array}{l}2 \\
5 \\
8 \\
\infty \\
5 \\
0 \\
0 \\
0\end{array}$ & 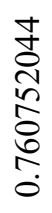 & 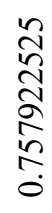 \\
\hline$\underset{\Xi}{\overparen{Z}}$ & $\begin{array}{l}\hat{o} \\
+ \\
\infty \\
\infty \\
\infty \\
i\end{array}$ & $\begin{array}{l}\hat{o} \\
+1 \\
\text { ñ } \\
\text { ñ }\end{array}$ & $\begin{array}{l}\text { o } \\
0 \\
\omega \\
\infty \\
\infty \\
- \\
-1\end{array}$ & $\begin{array}{l}\hat{o} \\
\text { 1 } \\
\text { ñ } \\
\text { ñ }\end{array}$ & $\begin{array}{l}8 \\
0 \\
1 \\
\\
\sigma \\
\dot{m}\end{array}$ & $\begin{array}{l}\hat{0} \\
1 \\
\infty \\
\infty \\
\\
\dot{n}\end{array}$ & $\begin{array}{l}\hat{0} \\
1 \\
\text { ஸे } \\
\infty \\
0 \\
0\end{array}$ \\
\hline 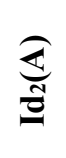 & $\begin{array}{l}\hat{o} \\
+1 \\
\text { to } \\
\stackrel{i}{i}\end{array}$ & $\begin{array}{l}\stackrel{ \pm}{t} \\
\stackrel{+}{\sigma} \\
\stackrel{\Delta}{i}\end{array}$ & $\begin{array}{l}\hat{\alpha} \\
\hat{1} \\
\bar{n} \\
a\end{array}$ & $\begin{array}{l}\frac{n}{1} \\
\underset{+}{*} \\
\underset{\forall}{*}\end{array}$ & $\begin{array}{l}\infty \\
0 \\
1 \\
\text { 11 } \\
\text { શ } \\
\text { i }\end{array}$ & 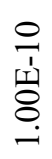 & 0 \\
\hline $\bar{\Rightarrow}$ & 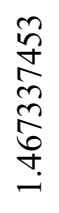 & 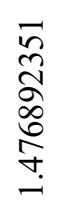 & $\begin{array}{l}\bar{\delta} \\
\text { } \\
\text { ᄋे } \\
\text {. }\end{array}$ & 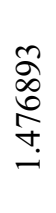 & 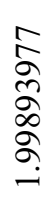 & 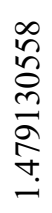 & $\begin{array}{l}\hat{a} \\
a \\
a \\
n \\
n \\
n\end{array}$ \\
\hline$\stackrel{\sim}{=}$ & 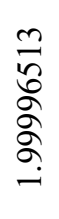 & $\begin{array}{l}\bar{a} \\
\infty \\
\infty \\
\infty \\
\infty \\
0 \\
n \\
n\end{array}$ & 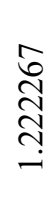 & 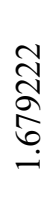 & 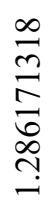 & 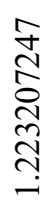 & - \\
\hline$\sum_{\boldsymbol{N}}^{\infty}$ & 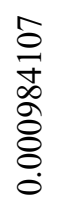 & $\begin{array}{l}\text { ठิ } \\
8 \\
\infty \\
8 \\
8 \\
8 \\
0\end{array}$ & $\begin{array}{l}\stackrel{\circ}{0} \\
\overline{8} \\
\dot{8} \\
0\end{array}$ & 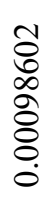 & $\begin{array}{l}8 \\
\stackrel{2}{8} \\
8 \\
\circ \\
8 \\
8 \\
0\end{array}$ & 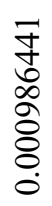 & 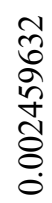 \\
\hline
\end{tabular}


Table 6. The real and output current for proposed and original algorithm.

\begin{tabular}{|c|c|c|c|c|c|c|c|c|}
\hline V real & I real & $\mathrm{EO}$ & TLBO & $\mathrm{HHO}$ & PSO & PO & MRFO & JAYA \\
\hline-0.2057 & 0.764 & 0.7641 & 0.7641 & 0.7635 & 0.7641 & 0.7612 & 0.7613 & 0.7579 \\
\hline-0.1291 & 0.762 & 0.7627 & 0.7627 & 0.7624 & 0.7627 & 0.7603 & 0.7601 & 0.7579 \\
\hline-0.0588 & 0.7605 & 0.7614 & 0.7614 & 0.7613 & 0.7614 & 0.7594 & 0.7590 & 0.7579 \\
\hline 0.0057 & 0.7605 & 0.7602 & 0.7602 & 0.7603 & 0.7602 & 0.7585 & 0.7580 & 0.7579 \\
\hline 0.0646 & 0.76 & 0.7591 & 0.7591 & 0.7593 & 0.7591 & 0.7577 & 0.7571 & 0.7579 \\
\hline 0.1185 & 0.759 & 0.7581 & 0.7580 & 0.7585 & 0.7580 & 0.7568 & 0.7562 & 0.7579 \\
\hline 0.1678 & 0.757 & 0.7571 & 0.7571 & 0.7576 & 0.7571 & 0.7557 & 0.7551 & 0.7578 \\
\hline 0.2132 & 0.757 & 0.7562 & 0.7561 & 0.7567 & 0.7561 & 0.7541 & 0.7537 & 0.7577 \\
\hline 0.2545 & 0.7555 & 0.7551 & 0.7551 & 0.7556 & 0.7551 & 0.7515 & 0.7514 & 0.7573 \\
\hline 0.2924 & 0.754 & 0.7537 & 0.7537 & 0.7540 & 0.7537 & 0.7470 & 0.7474 & 0.7564 \\
\hline 0.3269 & 0.7505 & 0.7514 & 0.7514 & 0.7515 & 0.7514 & 0.7394 & 0.7401 & 0.7544 \\
\hline 0.3585 & 0.7465 & 0.7473 & 0.7474 & 0.7471 & 0.7474 & 0.7265 & 0.7274 & 0.7503 \\
\hline 0.3873 & 0.7385 & 0.7401 & 0.7401 & 0.7395 & 0.7401 & 0.7062 & 0.7070 & 0.7426 \\
\hline 0.4137 & 0.728 & 0.7274 & 0.7274 & 0.7265 & 0.7274 & 0.6748 & 0.6753 & 0.7291 \\
\hline 0.4373 & 0.7065 & 0.7070 & 0.7070 & 0.7061 & 0.7070 & 0.6308 & 0.6308 & 0.7077 \\
\hline 0.4590 & 0.6755 & 0.6754 & 0.6753 & 0.6748 & 0.6753 & 0.5725 & 0.5720 & 0.6749 \\
\hline 0.4784 & 0.632 & 0.6309 & 0.6308 & 0.6308 & 0.6308 & 0.5004 & 0.4997 & 0.6296 \\
\hline 0.4960 & 0.573 & 0.5722 & 0.5719 & 0.5724 & 0.5721 & 0.4143 & 0.4138 & 0.5704 \\
\hline 0.5119 & 0.499 & 0.5000 & 0.4996 & 0.5004 & 0.4998 & 0.3178 & 0.3177 & 0.4983 \\
\hline 0.5265 & 0.413 & 0.4142 & 0.4137 & 0.4143 & 0.4139 & 0.2120 & 0.2124 & 0.4129 \\
\hline 0.5398 & 0.3165 & 0.3182 & 0.3175 & 0.3179 & 0.3179 & 0.1017 & 0.1026 & 0.3176 \\
\hline 0.5521 & 0.212 & 0.2130 & 0.2122 & 0.2120 & 0.2127 & -0.0091 & -0.0084 & 0.2130 \\
\hline 0.5633 & 0.1035 & 0.1033 & 0.1023 & 0.1017 & 0.1029 & -0.1256 & -0.1251 & 0.1036 \\
\hline 0.5736 & -0.01 & -0.0075 & -0.0087 & -0.0092 & -0.0079 & -0.2074 & -0.2080 & -0.0077 \\
\hline 0.5833 & -0.123 & -0.1241 & -0.1255 & -0.1257 & -0.1244 & 0.7612 & 0.7613 & -0.1253 \\
\hline 0.5900 & -0.21 & -0.2069 & -0.2084 & -0.2075 & -0.2073 & 0.7603 & 0.7601 & -0.2098 \\
\hline $\mathrm{V}$ real & I real & EO & TLBO & $\mathrm{HHO}$ & PSO & $\mathrm{PO}$ & MRFO & JAYA \\
\hline-0.2057 & 0.764 & 0.7641 & 0.7641 & 0.7635 & 0.7641 & 0.7612 & 0.7613 & 0.7579 \\
\hline
\end{tabular}




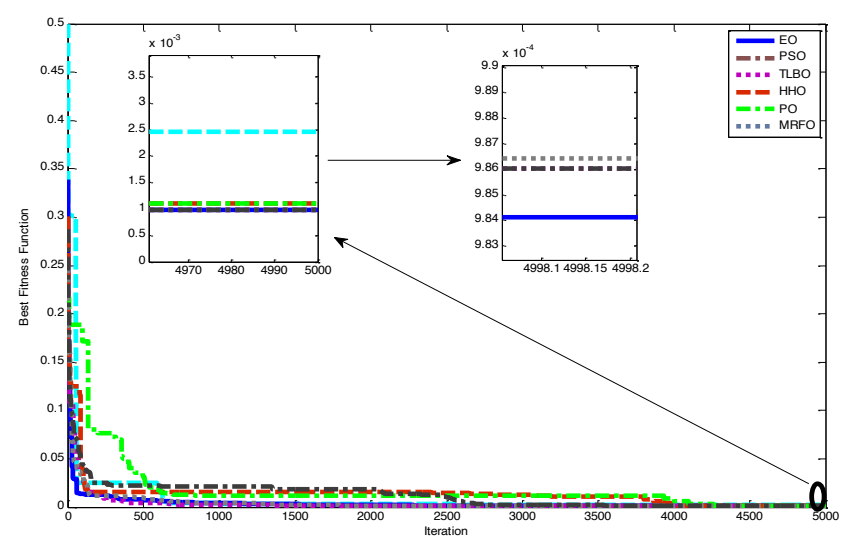

Figure 14. Fitness function for DD model for different optimization algorithms.

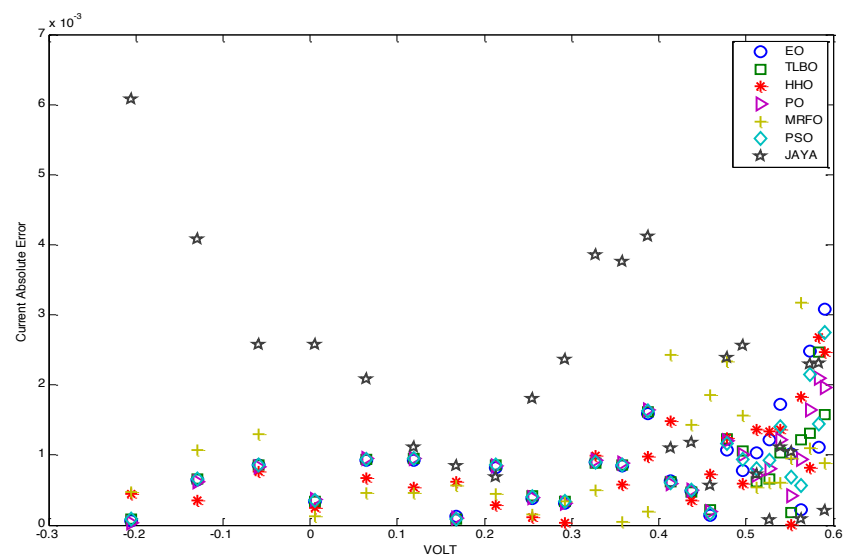

Figure 15. PV Output Current Absolute Error for EO and other algorithms.

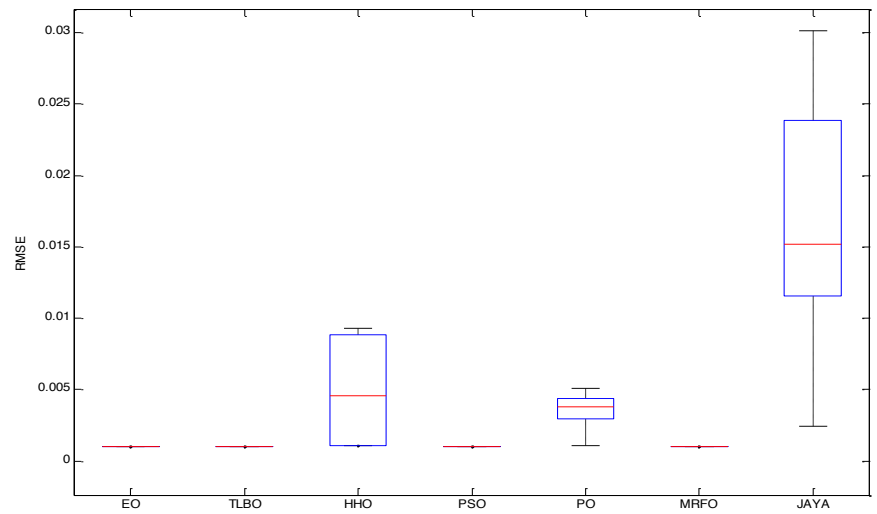

Figure 16. Boxplot for RMSE values of different algorithms for DD model. 
Table 7. The statistical results of all algorithms.

\begin{tabular}{|c|c|c|c|c|}
\hline & Minimum & Average & Maximum & STD \\
\hline EO & 0.0009841 & 0.00097494 & 0.00098602 & $1.30096 \mathrm{E}-06$ \\
\hline TLBO & 0.00098602 & 0.00099791 & 0.00102173 & $1.45777 \mathrm{E}-05$ \\
\hline HHO & 0.001109 & 0.0049636 & 0.0093 & 0.003956423 \\
\hline PSO & 0.00098602 & 0.00099079 & 0.00099905 & $5.6331 \mathrm{E}-06$ \\
\hline PO & 0.00110071 & 0.00354014 & 0.0051 & 0.001480586 \\
\hline MRFO & 0.00098644 & 0.00099014 & 0.00099735 & $4.50056 \mathrm{E}-06$ \\
\hline JAYA & 0.00245963 & 0.01683193 & 0.0301 & 0.010184928 \\
\hline
\end{tabular}

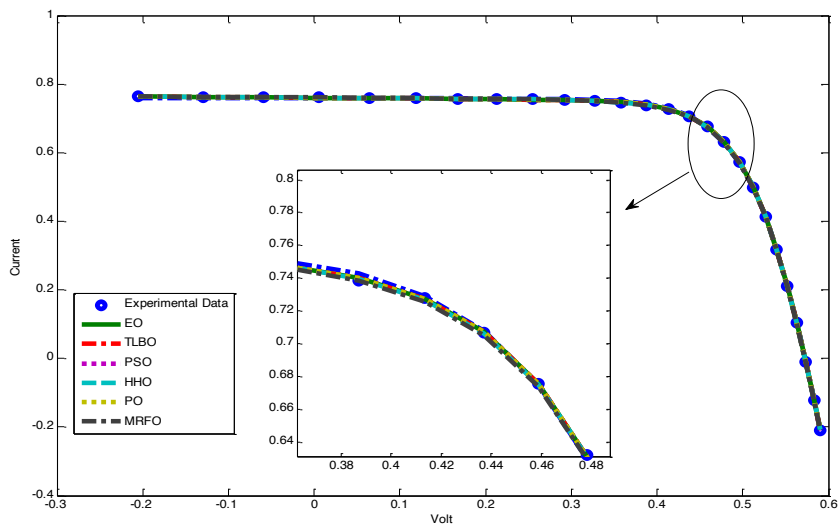

Figure 17. Current Vs volt characteristics for real system, EO and other algorithms.

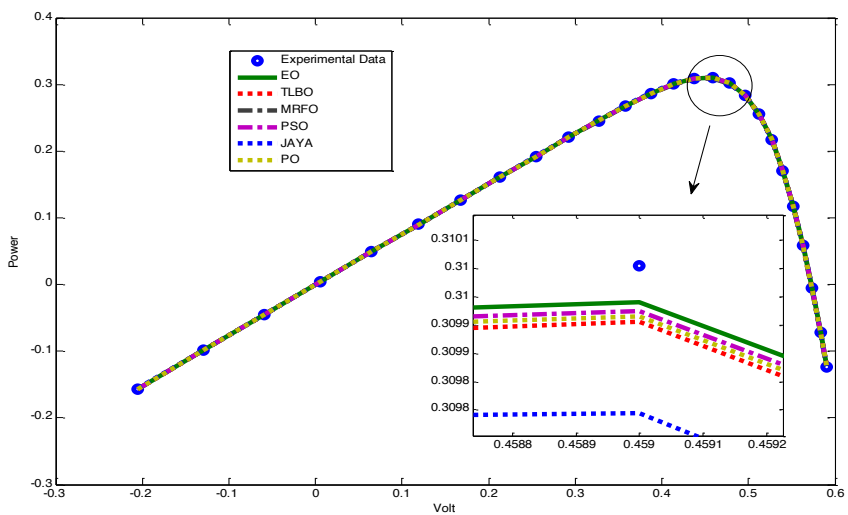

Figure 18. Power Vs volt characteristics for real system, EO and other algorithms. 


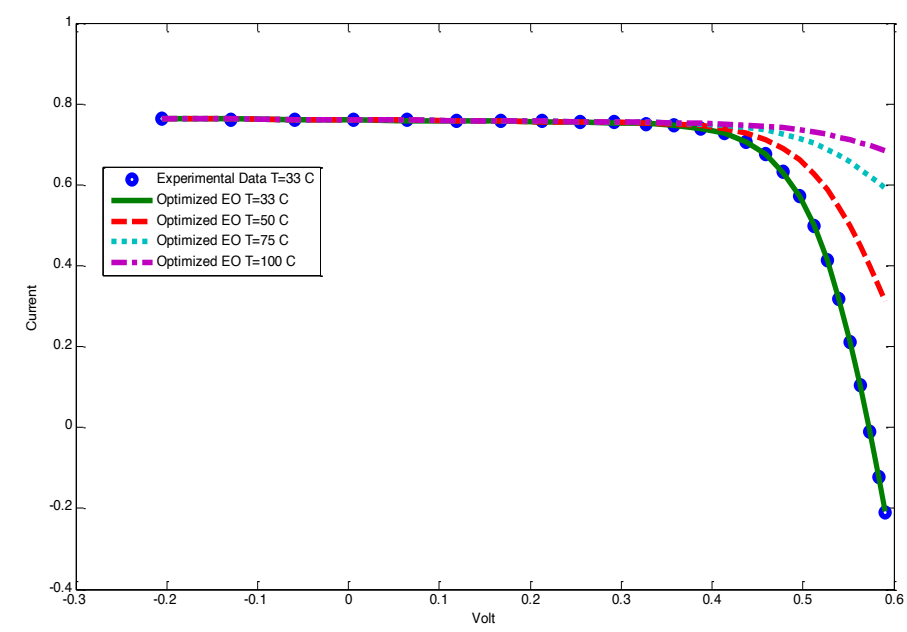

Figure 19. Current Vs volt characteristics for real system and $\mathrm{EO}$ algorithm at different temperatures.

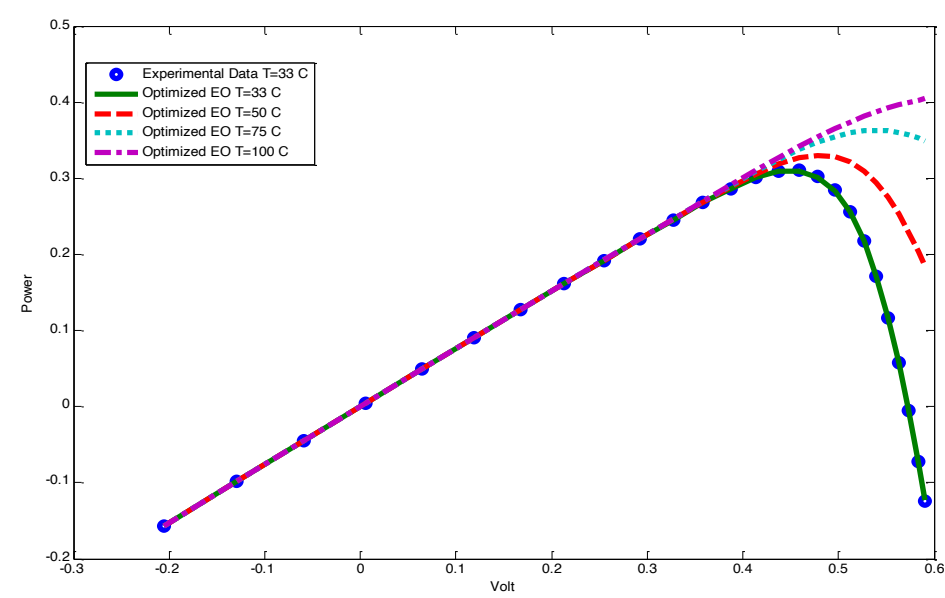

Figure 20. Power Vs volt characteristics for real system and EO algorithm at different temperatures.

\section{B. Application 2}

In this application, according to the optimization problem for TD model described in equation 9, EO is applied to estimate nine parameters for TD PV model. The real data considered in this application are the data measured from a polycrystalline PV panel STM6-120/36 [34]. The panel has open-circuit voltage $V_{o c}=19.21$ and short-circuit current $I_{s c}=7.48 \mathrm{~A}$. The measured data from the panel at temperature $55 \mathrm{C}$ are listed in Table 8 . Also, the calculated output current from the estimated parameter for TD model by EO is presented in Table 8. The estimated parameters and RMSE for EO and other compared algorithms are listed in Table 9. Fig. 21 presents the convergence curves for all algorithms. The RMSE values calculated in each run in the statistical results are figured in boxplot for each algorithm as shown in fig. 22. (+) represents the outliers. The statistical results for 30 runs are presented in table 10. Fig. 23 presents the absolute error between real output current and the output current calculated from the parameter estimated from each algorithm. In figs. 21, 22, and 23, EO algorithm results are more accurate than those of others. For more 
comparison, current Vs volt and power Vs volt characteristics curves for real system, EO, and other algorithms have been discussed in figs. 24 and 25, respectively. The accuracy of the DD model developed by EO algorithm is tested through the current Vs volt and power Vs volt characteristics curves at different temperatures as shown in figs. 26 and 27 , respectively.

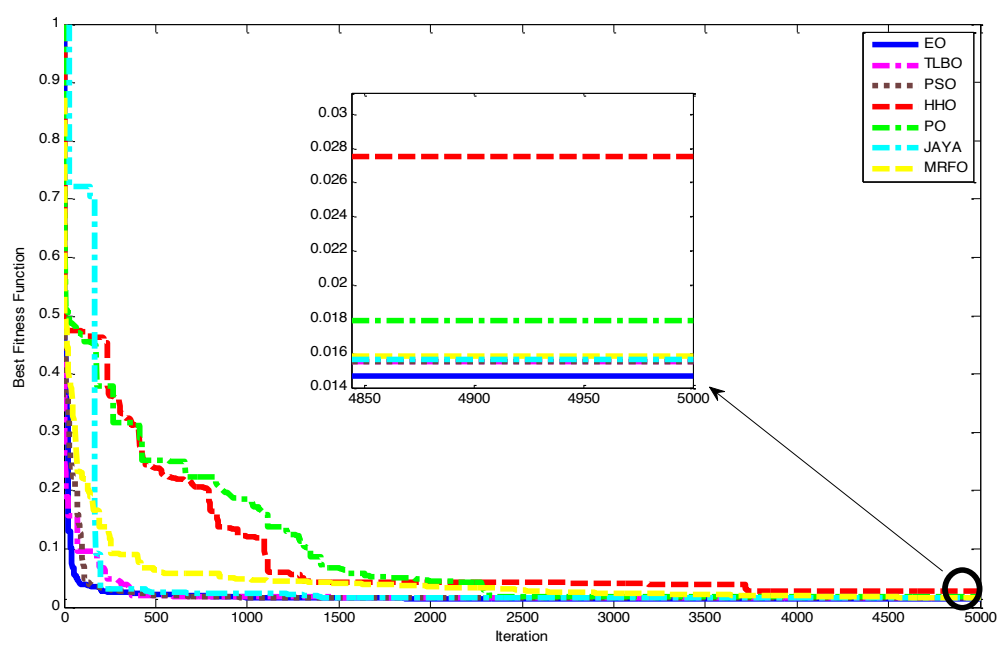

Figure 21. Fitness function of TD model for different optimization algorithms.

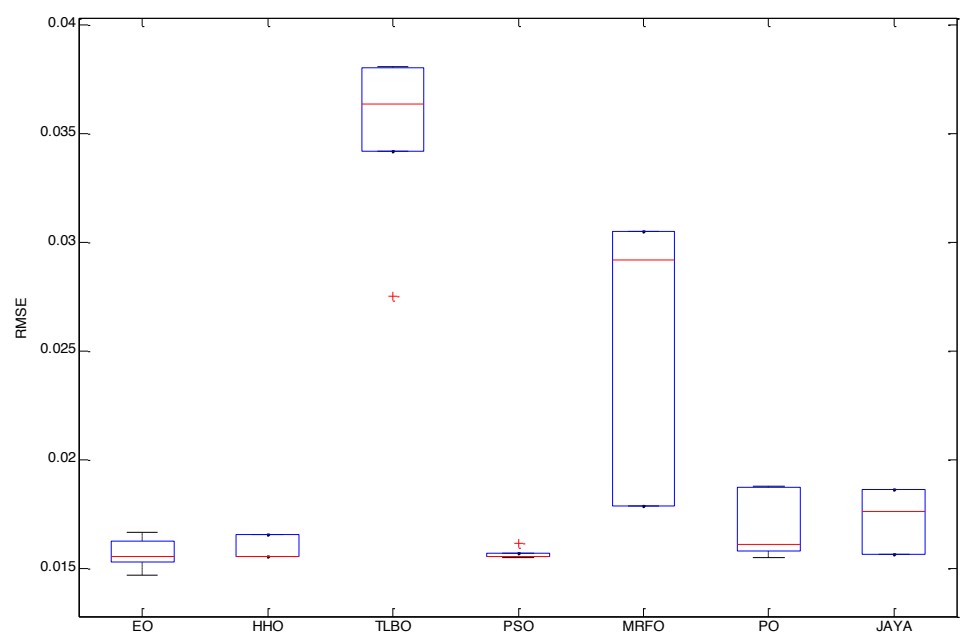

Figure 22. Boxplot for RMSE values of different algorithms for TD model. 
Table 8. The real and output current for the proposed and original algorithm.

\begin{tabular}{|c|c|c|c|c|c|c|c|c|}
\hline$V_{\text {real }}$ & $I_{\text {real }}$ & $E O$ & $T L B O$ & ННО & PSO & $P O$ & MRFO & $J A Y A$ \\
\hline 17.65 & 3.83 & 3.8467 & 3.8455 & 3.7908 & 3.8553 & 3.8610 & 3.8371 & 3.8588 \\
\hline 17.41 & 4.29 & 4.2695 & 4.2615 & 4.2615 & 4.2715 & 4.2634 & 4.2600 & 4.2725 \\
\hline 17.25 & 4.56 & 4.5395 & 4.5290 & 4.5487 & 4.5386 & 4.5313 & 4.5301 & 4.5387 \\
\hline 17.10 & 4.79 & 4.7807 & 4.7692 & 4.7988 & 4.7783 & 4.7745 & 4.7718 & 4.7780 \\
\hline 16.90 & 5.07 & 5.0799 & 5.0691 & 5.1036 & 5.0775 & 5.0781 & 5.0727 & 5.0769 \\
\hline 16.76 & 5.27 & 5.2650 & 5.2575 & 5.2953 & 5.2653 & 5.2625 & 5.2616 & 5.2646 \\
\hline 16.34 & 5.75 & 5.7729 & 5.7701 & 5.7961 & 5.7760 & 5.7776 & 5.7733 & 5.7757 \\
\hline 16.08 & 6.00 & 6.0369 & 6.0361 & 6.0510 & 6.0408 & 6.0445 & 6.0380 & 6.0409 \\
\hline 15.71 & 6.36 & 6.3401 & 6.3427 & 6.3479 & 6.3463 & 6.3455 & 6.3434 & 6.3466 \\
\hline 15.39 & 6.58 & 6.5647 & 6.5665 & 6.5597 & 6.5691 & 6.5711 & 6.5657 & 6.5698 \\
\hline 14.93 & 6.83 & 6.8181 & 6.8180 & 6.7993 & 6.8195 & 6.8237 & 6.8156 & 6.8205 \\
\hline 14.58 & 6.97 & 6.9655 & 6.9639 & 6.9402 & 6.9649 & 6.9694 & 6.9608 & 6.9658 \\
\hline 14.17 & 7.10 & 7.0971 & 7.0943 & 7.0692 & 7.0949 & 7.0978 & 7.0909 & 7.0957 \\
\hline 13.59 & 7.23 & 7.2263 & 7.2231 & 7.2013 & 7.2234 & 7.2225 & 7.2199 & 7.2237 \\
\hline 13.16 & 7.29 & 7.2911 & 7.2881 & 7.2711 & 7.2884 & 7.2846 & 7.2854 & 7.2883 \\
\hline 12.74 & 7.34 & 7.3361 & 7.3336 & 7.3223 & 7.3339 & 7.3278 & 7.3316 & 7.3334 \\
\hline 12.36 & 7.37 & 7.3656 & 7.3638 & 7.3578 & 7.3640 & 7.3568 & 7.3623 & 7.3633 \\
\hline 11.81 & 7.38 & 7.3951 & 7.3943 & 7.3957 & 7.3946 & 7.3871 & 7.3937 & 7.3934 \\
\hline 11.17 & 7.41 & 7.4160 & 7.4162 & 7.4254 & 7.4165 & 7.4109 & 7.4167 & 7.4151 \\
\hline 10.32 & 7.44 & 7.4312 & 7.4325 & 7.4501 & 7.4328 & 7.4325 & 7.4342 & 7.4311 \\
\hline 9.74 & 7.42 & 7.4369 & 7.4389 & 7.4611 & 7.4391 & 7.4440 & 7.4413 & 7.4374 \\
\hline 9.06 & 7.45 & 7.4409 & 7.4434 & 7.4701 & 7.4436 & 7.4554 & 7.4465 & 7.4418 \\
\hline
\end{tabular}


Table 9. Estimated parameter in case of TD model obtained by different optimization algorithms.

\begin{tabular}{|c|c|c|c|c|c|c|c|}
\hline & 오 & 율 & $\stackrel{\vartheta}{\underline{\underline{\Xi}}}$ & ஜ & $\stackrel{0}{0}$ & 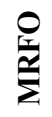 & 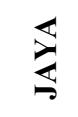 \\
\hline$\underset{\tilde{\simeq}}{\widehat{\text { CI}}}$ & $\begin{array}{l}\hat{n} \\
\hat{n} \\
\hat{n} \\
0\end{array}$ & \begin{tabular}{l}
$\stackrel{0}{\circ}$ \\
\multirow{2}{*}{$n$} \\
$\stackrel{2}{0}$ \\
0 \\
0
\end{tabular} & $\begin{array}{l}\text { I } \\
\overrightarrow{5} \\
\infty \\
0 \\
0 \\
0\end{array}$ & $\begin{array}{l}\overrightarrow{0} \\
\frac{\sigma}{2} \infty \\
\stackrel{2}{0} \infty \\
0\end{array}$ & 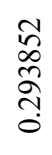 & $\begin{array}{l}8 \\
0 \\
0 \\
0 \\
0 \\
0\end{array}$ & $\begin{array}{l}\overrightarrow{\vec{m}} \\
\stackrel{2}{\infty} \infty \\
\stackrel{2}{a} \\
\dot{0}\end{array}$ \\
\hline 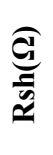 & ষ্ণ & 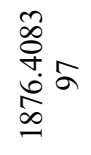 & $\begin{array}{l}\hat{8} \\
\hat{n} \\
\dot{+} \\
\text { ते }\end{array}$ & $\begin{array}{l}\text { बे } \\
\text { बे } \\
\text { बे }\end{array}$ & $\begin{array}{l}\frac{\infty}{0} \\
\stackrel{2}{r} \\
\stackrel{2}{r}\end{array}$ & $\begin{array}{l}n \\
n \\
0 \\
0 \\
0 \\
0\end{array}$ & 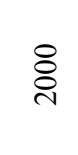 \\
\hline 这 & 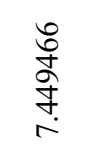 & 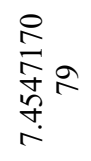 & $\frac{n}{\stackrel{n}{n}}$ & 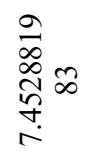 & $\begin{array}{l}0 \\
\overrightarrow{0} \\
0 \\
0 \\
i\end{array}$ & 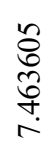 & 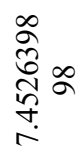 \\
\hline$\underset{\Xi}{\Xi}$ & 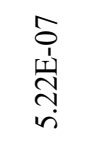 & $\begin{array}{l}\frac{1}{1} \\
\frac{1}{1} \\
0 \\
\dot{m}\end{array}$ & $\begin{array}{l}0 \\
0 \\
1 \\
1 \\
0 \\
0 \\
\text { i }\end{array}$ & 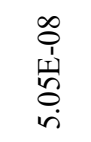 & $\begin{array}{c}0 \\
0 \\
1 \\
1 \\
0 \\
0 \\
-1\end{array}$ & $\begin{array}{l}\hat{0} \\
\stackrel{\circ}{8} \\
0 \\
0\end{array}$ & 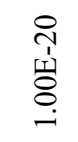 \\
\hline ্ָত & 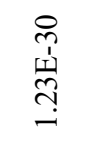 & 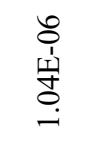 & $\begin{array}{l}8 \\
0 \\
1 \\
\text { ஸ1 } \\
n \\
+\end{array}$ & 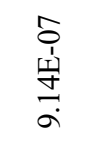 & $\begin{array}{l}\infty \\
0 \\
1 \\
1 \\
0 \\
0 \\
0\end{array}$ & $\begin{array}{l}\text { ते } \\
\text { ठे } \\
\text { ¿. }\end{array}$ & $\begin{array}{l}\hat{o} \\
\text { i⿱ } \\
\stackrel{1}{N} \\
a\end{array}$ \\
\hline 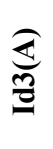 & 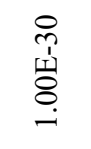 & 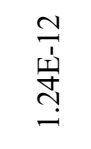 & 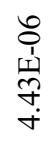 & 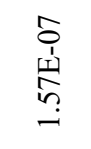 & 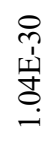 & 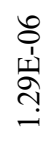 & $\begin{array}{l}\text { ㄱ. } \\
\text { 1 } \\
\text { ஸे } \\
\stackrel{-}{-}\end{array}$ \\
\hline 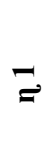 & $\begin{array}{l}\overrightarrow{\mathbb{N}} \\
\stackrel{\delta}{\vec{j}} \\
\dot{\forall}\end{array}$ & $\begin{array}{l}\hat{\hat{\sigma}} \\
\text { on } \\
\stackrel{\sigma}{\dot{+}}\end{array}$ & in & 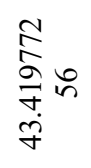 & 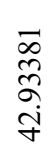 & $\begin{array}{l}\overrightarrow{\tilde{O}} \\
0 \\
\dot{0} \\
\vec{n}\end{array}$ & in \\
\hline$\stackrel{\Re}{=}$ & 오 & $\begin{array}{l}\tilde{n} \\
\hat{2} \\
8 \\
0 \\
\dot{\sigma} \\
\dot{\sigma}\end{array}$ & in & 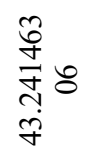 & $\underset{\substack{n\\
}}{\stackrel{n}{n}}$ & 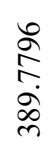 & $\begin{array}{l}\stackrel{\tilde{n}}{\sigma} \\
\tilde{a} \\
\stackrel{y}{y}\end{array}$ \\
\hline$\stackrel{m}{=}$ & $\begin{array}{l}0 \\
\stackrel{0}{0} \\
\stackrel{0}{0} \\
\stackrel{0}{\sigma}\end{array}$ & in & in & $\begin{array}{l}\vec{n} \\
\hat{\sigma} \\
\vdots \\
\dot{\sigma} \\
\dot{\sigma}\end{array}$ & $\frac{\stackrel{0}{N}}{\stackrel{N}{N}}$ & 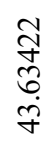 & 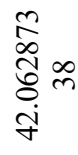 \\
\hline$\sum_{\simeq}^{\infty}$ & 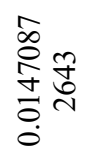 & $\begin{array}{l}\infty \\
0 \\
\tilde{n} \\
\tilde{n} \\
\vdots \\
0 \\
0\end{array}$ & 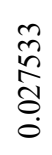 & $\begin{array}{l}\infty \\
\stackrel{0}{n} \\
\stackrel{n}{n}+ \\
\vdots \\
0\end{array}$ & $\begin{array}{l}n \\
2 \\
\stackrel{2}{\sigma} \\
0 \\
0\end{array}$ & $\begin{array}{l}0 \\
\infty \\
\infty \\
n \\
0 \\
0\end{array}$ & 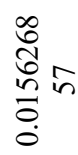 \\
\hline
\end{tabular}


Table 10. The statistical results of all algorithms.

\begin{tabular}{|c|c|c|c|c|}
\hline & Minimum & Average & Maximum & STD \\
\hline EO & 0.01470873 & 0.01571738 & 0.01667917 & 0.000740527 \\
\hline TLBO & 0.01555087 & 0.01595619 & 0.01656268 & 0.000553647 \\
\hline PHO & 0.027533 & 0.0352866 & 0.0381 & 0.004412352 \\
\hline PO & 0.01551985 & 0.01565567 & 0.01614341 & 0.000272778 \\
\hline MRFO & 0.015508 & 0.0170016 & 0.0188 & 0.001610594 \\
\hline JAYA & 0.01562686 & 0.01722686 & 0.01862686 & 0.001516575 \\
\hline
\end{tabular}

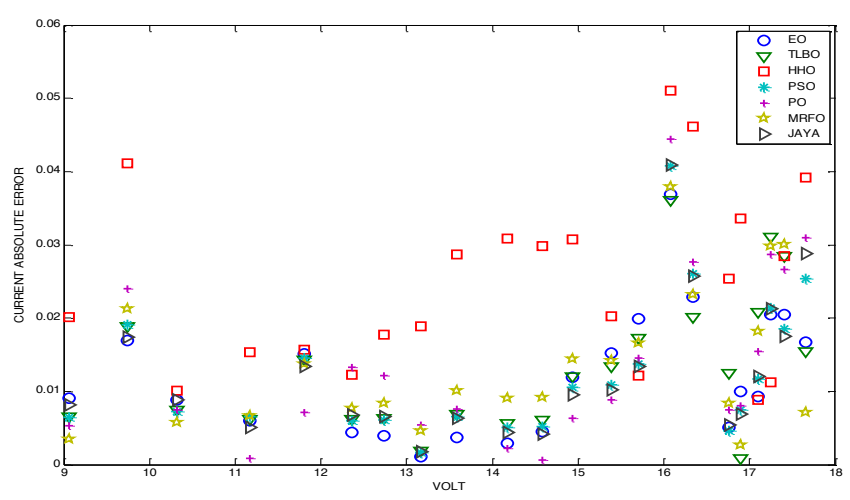

Figure 23. PV Output Current Absolute Error for EO and other algorithms.

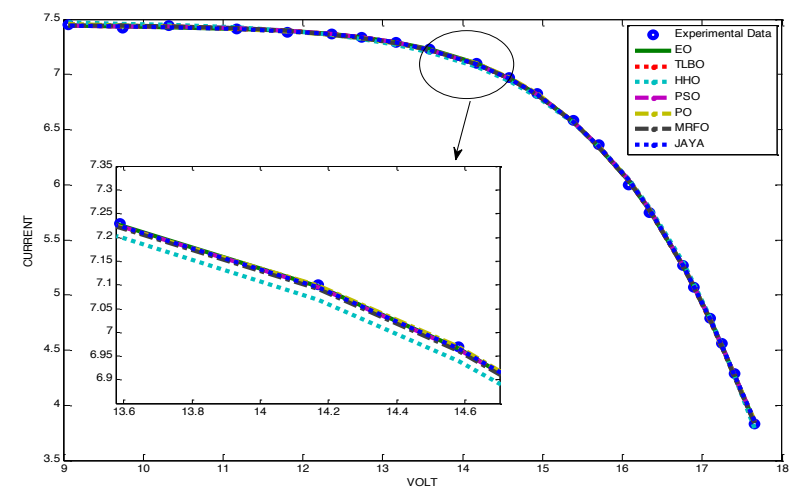

Figure 24. Current Vs volt characteristics for real system, EO and other algorithms. 


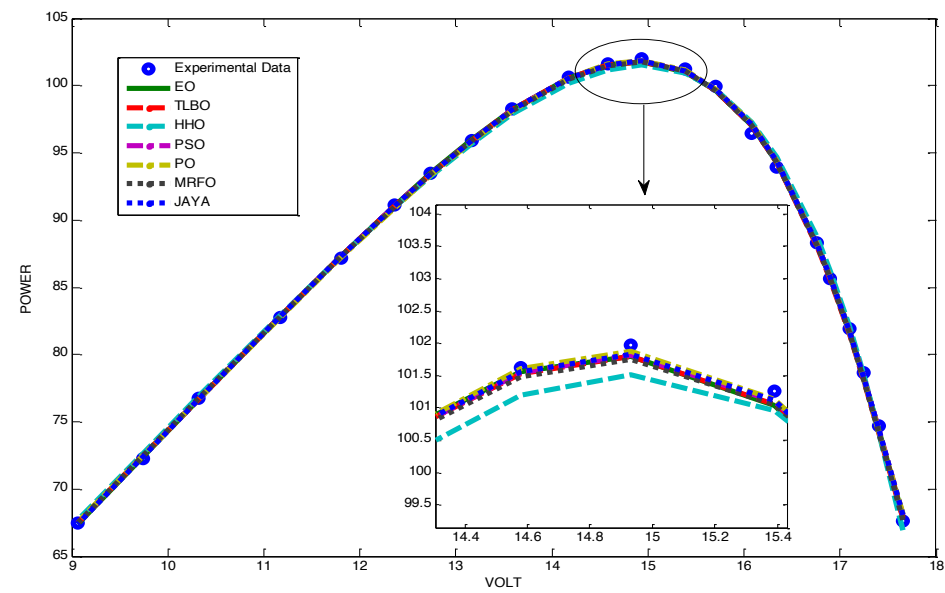

Figure 25. Power Vs volt characteristics for real system, EO, and other algorithms.

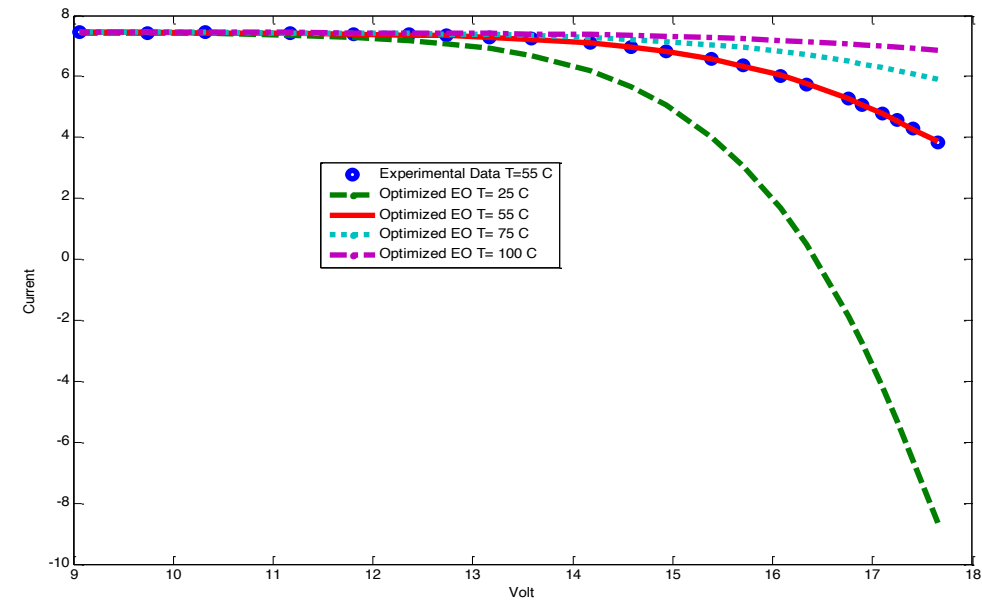

Figure 26. Current Vs volt characteristics for real system and EO algorithm at different temperatures.

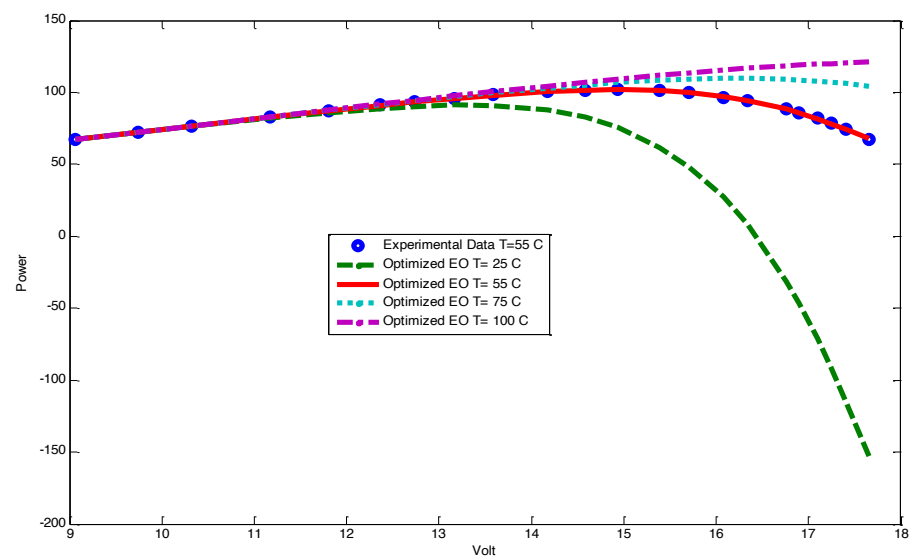

Figure 27. Power Vs volt characteristics for real system and EO algorithm at different temperatures. 


\section{CONCLUSION}

In this paper, the most recent three PV models have been discussed (SD, DD, and TD models), and also, an EO algorithm has been discussed and applied for solving the optimal parameter estimation of different PV models. The EO has been tested though parameter estimation of SD and DD and PV models through real PV system. In addition, it has been applied for estimating the parameters for polycrystalline PV panels through TD PV model. The comparison between EO and other algorithms has been covered by comparing different evaluation parameters, for example, RMSE and absolute error. In all cases, the results obtained by EO are more accurate than those obtained by the other optimization algorithms.

\section{REFERENCES}

L. El Chaar, N. EI Zein et al., "Review of photovoltaic technologies," Renewable and sustainable energy reviews, vol. 15 , no. 5, pp. 2165-2175,2011.

S. Adams, EKM. A. Klobodu, Apio. "Renewable and non-renewable energy, regime type and economic growth,”. Renew Energy, pp. 125-755e67. 2018.

JK. Mannekote, SV. Kailas, K. Venkatesh, N. Kathyayini. "Environmentally friendly functional fluids from renewable and sustainable sources-a review,”. Renew Sustain Energy Vol. 81, 2018.

R. Abbassi, A. Abbassi, M Jemli and S. Chebbi "Identification of unknown parameters of solar cell models: A comprehensive overview of available approaches," Renewable and Sustainable Energy Reviews., vol. 90, pp. 453-474, Jan. 2018.

ZUOWEN. LIAO, ZHIKUN CHEN and SHUIJIA. LI "Parameters extraction of photovoltaic models using triple-phase teaching-learning-based optimization," IEEE Access., vol. 4.,2016

X. Chen,. Y. Du, H. Wen, L. Jiang, W. Xiao, "Forecasting-based power ramp-rate control strategies for utilityscale PV systems.” IEEE Trans. Ind. Electron., Vol. 66, PP.1862-1871, 2019

M. Jamadi, F. M.Bayat and M. Bigdeli. "Very accurate parameter estimation of single- and double-diode solar cell models using a modified artificial bee colony algorithm". Int J Energy Environ Eng vol. 7, pp.13-25, 2016.

A. Abbassi , R.Gammoudi, M.A. Dami, O. Hasnaoui and M. Jemli "An improved single-diode model parameters extraction at different operating conditions with a view to modeling a photovoltaic generator: A comparative study" Solar Energy, vol. 155, pp. 478-489, (2017)

S. Bana, and RP. Saini. "Identification of unknown parameters of a single diode photovoltaic model using particle swarm optimization with binary constraints," Renew Energy, vol. 101, PP. 1299-310, 2017

X. Gao, Y. Cui, Hu J, Xu G and Yu Y. "Lambert w-function based exact representation for double diode model of solar cells: comparison on fitness and parameter extraction," Energy Convers Manage. vol. 127, PP.44360. 2016.

A. Dehghanzadeh, G. Farahani, M. Maboodi. "A novel approximate explicit double-diode model of solar cells for use in simulation studies” Renew Energy, vol. 103,pp. 468-77,2017.

K. Et-torabi, I. Nassar-eddine, A. Obbadi, Y. Errami, R. Rmaily, S .Sahnoun, A. El fajri, and M. Agunaou "Parameters estimation of the single and double diode photovoltaic models using a Gauss-Seidel algorithm and analytical method: a comparative study," Energy Convers Manag, vol. 148, pp. 1041-54, 2017.

S. Gupta, H. Tiwari, M. Fozdar, V. Chandna, "Development of a two diode model for photovoltaic modules suitable for use in simulation studies," In Proceedings of the 2012 Asia-Pacific Power and Energy Engineering Conference, Shanghai, China, 27-29, pp. 1-4, March 2012. 
S. Omnia, H.M. Elazab, M.A.E. Hasanien, A.M. "Abdeen, Parameters estimation of single- and multiple-diode photovoltaic model using whale optimisation algorithm," IET Renew. Power Gener. vol. 12, pp.1755-1761. 2018.

O. R. Elazab, H. A. Hasanien, I. Alsaidan, A.Y. Abdelaziz and S. M. Muyeen "Parameter Estimation of Three Diode Photovoltaic Model Using Grasshopper Optimization Algorithm,” Energies, vol. 13, pp. 497, Jan. 2020.

D. Allam, D.A. Yousri and M.B. Eteiba "Parameters extraction of the three diode model for the multi-crystalline solar cell/module using Moth-Flame Optimization Algorithm," Energy Conversion and Management, vol. 123, pp. 535-548, Jan. 2016.

D. Allam, DA. Yousri, MB. Eteiba. "Parameters extraction of the three diode model for the multi-crystalline solar cell/module using moth-flame optimization algorithm," Energy Convers Manag. vol. 123, pp. 535-48, 2016.

M.H. Qais, H.M. Hasanien, S. Alghuwainem and A.S. Nouh, "Coyote optimization algorithm for parameters extraction of three-diode photovoltaic model of photovoltaic modules," Energy 2019, 187, 1-8.

N. T. Tong, K. Kamolpattana, and W. Pora, "A deterministic method for searching the maximum power point of a pv panel," in 2015 12th International Conference on Electrical Engineering/Electronics, Computer, Telecommunications and Information Technology (ECTI-CON). IEEE, pp. 1-6, 2015.

M. Das, MAK. Singh, A. Biswas. "Techno-economic optimization of an off-grid hybrid renewable energy system using metaheuristic optimization approaches - Case of a radio transmitter station in India,"Energy Convers Manage, vol.185: pp. 339-52, 2019.

A.Ramadan ,S. Kamel, A. korashy and J.Yu "Photovoltaic Cells Parameter Estimation Using an Enhanced Teaching Learning Based Optimization Algorithm" Iranian Journal of Science and Technology, Transactions of Electrical Engineering.

M. Singh, B. Panigrahi, and A. Abhyankar, "Optimal coordination of directional over-current relays using Teaching Learning-Based Optimization (TLBO) algorithm," International Journal of Electrical Power \& Energy Systems, vol. 50, pp. 33-41, 2013.

X. Chen, B. Xu, C. Mei, Y. Ding and K. Li ."Teaching-learning-based artificial bee colony for solar photovoltaic parameter estimation", Applied Energy ,vol. 212, 1578-1588, 2018.

J.D. Bastidas-Rodriguez, G. Petrone, C.A. Ramos-Paja and G. Spagnuolo, "A genetic algorithm for identifying the single diode model parameters of a photovoltaic panel" Mathematics and Computers in Simulation, vol. 131, pp.38-54, 2017.

AA .Heidari, A. Abbaspour and H . Chen. "Efficient boosted grey wolf optimizers for global search and kernel extreme learning machine training," Appl Soft Comput,vol. 81,2019.

S. Mirjalili, S. M. Mirjalili, and A. Lewis, "Grey wolf optimizer," Advances in engineering software, vol. 69, pp. 46-61, 2014.

A.A. Heidari ,S. Mirjalili , H. Faris ,I .Aljarah M. Mafarja and H. Chen "Harris hawks optimization: Algorithm and applications" Future Generation Computer Systems.

M. Merchaoui, A. Sakly and M. F. Mimouni. "Particle swarm optimization with adaptive mutation strategy for photovoltaic solar cell/module parameter extraction" Energy Conversion and Management 175 (2018) 151163.

J.J. Soon and K-S. Low "Photovoltaic Model Identification Using Particle Swarm Optimization With Inverse Barrier Constraint" IEEE TRANSACTIONS ON POWER ELECTRONICS, VOL. 27, NO. 9, SEPTEMBER 2012. 
A. R. Jordehi "Enhanced leader particle swarm optimization (ELPSO): An efficient algorithm for parameter estimation of photovoltaic (PV) cells and modules" Solar Energy, vol. 159, pp. 78-87, 2018.

D. Oliva, M. Abd El Aziz and A. Hassanien "Parameter estimation of photovoltaic cells using an improved chaotic whale optimization algorithm", Applied Energy vol. 200, pp. 141-154, 2017.

D. Oliva, M. Abd El Aziz and A. Hassanien "Parameter estimation of photovoltaic cells using an improved chaotic whale optimization algorithm", Applied Energy vol. 200, 141-154, 2017.

A. Faramarzi, M. Heidarinejad,B. Stephens,S. Mirjalili "Equilibrium optimizer: A novel optimization algorithm," Knowledge-Based Systems,2019.

D. Oliva, A. A. Ewees, M. Abd El Aziz, A. E. Hassanien and M. P. Cisneros. "A Chaotic Improved Artificial Bee Colony for Parameter Estimation of Photovoltaic Cells,” Energies 2017. 